\title{
IS ELEGANCE PROOF? \\ STRUCTURALISM AND AFRICAN HISTORY ${ }^{1}$
}

Jan Vansina

University of Wisconsin-Madison

I

Despite its very visible career in anthropology and folklore, structuralism has been little used by historians of precolonial Africa. Only Ronald Atkinson has applied the method of LéviStrauss in the Edmund Leach variant, although a number of historians have attempted to elucidate symbolic meanings by other means. ${ }^{2}$ Rather surprisingly as well, given the two decades or so that have elapsed since Lévi-Strauss developed its axioms and analysis, no historian of Africa has ventured to discuss the validity of structuralism for coping with the interpretation of myths of origin or other oral traditions, except in passing. The topic has surfaced only here and there in the never-ending debate about traditions as expressions of the present, or of the past, or of both. Given the influence of structuralism elsewhere, though, it is due time that the approach be discussed for its own sake.

The reticence to do so became especially incongruous when a senior structuralist, Luc de Heusch, began to cover ground that historians had recently trod. In his te roi ivre he discussed at length myths in the kingdoms of southeastern Zaire and adjacent areas. ${ }^{3}$ This did prompt publication of two articles about his Luba and Lunda interpretations, but no general assessment of this work in toto. Jeffrey Hoover faulted de Heusch's Lunda material but still praised his "provocative ideas" and the method, "which bore some good fruit," while Thomas Reefe prefaced his critique of Luba material by calling the book "stimulating" and sidestepped the issue by noting that "no matter what the final assessment of this book will be by historians..." others were equally bland in their references to this work, while still refuting de Heusch on specifics. ${ }^{5}$ Everyone felt, it seems, that a general assessment was beyond or outside their competence. Yet a general critique would have been of use for de Heusch is one of the oldest and most experienced structuralists in anthropology, perhaps the first disciple of Lévi-Strauss. Trained in Paris, he imbibed the approaches of the Griaule school, the protostructuralism of Georges Dumézil, and the early teaching of the master himself. Of all structuralists he remains the most faithful to the method of Lévi-Strauss.

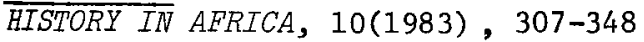


Inevitably, at some point structuralists would claim that structurally-analyzed myths could uncover "real" history. A vocal advocate of this position is Roy Willis, who was innocent of Dumézil and not well-versed in Lévi-Strauss, but a Leachian, at least when he published his Herskovits lecture. ${ }^{6}$ When he published his final analysis of Fipa traditions, however, his conclusions were rather different and his interpretations were no longer strictly structuralist. Now he relied on exegesis, with rather free interpretation of the results, going so far as to claim that his "key myth" can readily be translated into key Marxist concepts! ${ }^{7}$

Whatever his claims to structuralist credentials, Willis is not a representative author of this movement, even if he is a symbolic anthropologist of the Mary Douglas vintage. But de Heusch is, and his claims that structuralism contributes to history must be taken seriously. Adumbrated in 1972, his views have crystallized in his Rois nés d'un coeur de vache. This volume, the second in a proposed trilogy about Bantu myths and ritual, covers a much larger territory than Le roi ivre and holds views no historian can ignore since they deal with "the archeology of Bantu thought." Moreover de Heusch issues a direct challenge to "ethnohistorians" (338-66) that must be met, not only because of the ambiguity of reactions to his earlier work, but perhaps even more because he writes so well and so persuasively--and yet... So, perhaps nolens volens, I take up this challenge and broaden it by both examining the book as a paradigm of the method and judging the method by the book. ${ }^{8}$

This Bovine Womb is ambitious in scope. An introductory chapter again argues that sacred kingship is a symbolic structure and cannot be explained away by functionalism. Sacred kingship is a lifelong interest of de Heusch, who in a way is a critical continuator of James Frazer of Golden Bough fame. Here we are told that myths in "Bantu Africa" encapsulate the symbo1ic structure of kingship. Then a sequence of chapters making up half of the book examines historical tales as myth and ritual of kingship in Rwanda. This is not really linked to the second half, which itself consists of three blocks. One chapter discusses the Ncwala ritual of the Swazi, a Zocus classicus in anthropology. Two more discuss myths from the Venda and "Karanga," while two more analyze rites of passage, expecially boys" initiations, first among the Thonga and other southeastern African peoples, then comparatively.

As in all works of de Heusch, parentheses, excursuses, and obiter dicta abound. They are the major means by which comparative materials from Central Africa (often from The Drunken King) are woven into the tapestry. His goals are those of Lévi-Strauss: to show the mythical mind at work. They are also those of Dumézil: to show that contemporary myths reflect at least a common (in this case Bantu) myth of origin (9). Moreover, he builds up a history of events to show that boys' initiation rituals were exported from southeastern Africa to central Africa after 1836 and then spread there (10-11). He claims that a number of institutions, including kingship, obey the laws of structuralist 
history in Africa and sets himself off from functionalists and "ethnohistorians" (as well, I might add, from all Marxian thought). Functionalists confuse the symbolic structure of sacred kingship with the empirical developments of the state, which they help shape. This is implicit throughout the book (where Max Gluckman serves as its hero) and has in fact been an axiom in de Heusch's writings at least since 1958 when he wrote Essais sur le symbolisme de l'inceste royal en Afrique. As to "ethnohistorians," they are haunted by the chronology of events and remain indifferent to the very "long time spans" ("temps longs," not "longue durée") of structural transformations.

Keeping our goal in mind, I begin by presenting and criticizing structuralism per se, then move to the chapters about Rwanda, to see in a concrete fashion how structuralists work. Only then will I turn to the historical claims, the Dumézil face of this Janus figure. There I will start with specific historical claims, examine the grand Bantu hypothesis, and finally reach the discussion of "the archeology of myths." To follow the volume step-by-step would not make sense; the parts are merely connected loosely and the Daedalus of asides would turn any such discussion into confusion confounded.

\section{Structuralism}

Structuralists strive to uncover the laws that regulate the production of human thought, as Lévi-Strauss tried to do in his Mythologiques, the inspiration for these "mythes et rites bantous." This is a goal here, but there is a clearer assertion that a Bantu cosmology exists and that there are Ur-Bantu myths associated with sacred kingship. To structuralists generally, myths are narratives whose meanings are veiled. They express a "basic tension" (social or other) and "painful truths" through metaphors. Veiling is essential both because of the pain provoked by the naked truth and because of its awesome majesty. In practice such views of myth have close Freudian affinities.

As a set of operations, structural analysis consists of the following:

(i) set up oppositions between symbols in a text so that relationship yields a meaning. The closer the similarity between the terms of the opposition--except for the crucial difference--the clearer and the more elegant the meaning. Here the example of phonological opposition has been important: thus a : : b.

(ii) set up equivalences between oppositions drawn from a corpus of mythical texts. thus $a:: b$ and $c:: d$, written as $a: c:: b: d$.

(iii) parallels between several results obtained in (ii) yield transformations of mythical meaning; thus at the simplest, where $a:: b$, we can replace a by $c$; more often: 
$a: c:: b: d$ as: e:g : : $f: h$ and e:g :: b:d or a:c :: f:h.

(iv) these operations allow sequences in myths to be explained by sequences in other myths and allow whole myths to be seen as equivalents, opposites, or developments of each other. The notion of mediating terms is important here. thus if $a: c:: b: d$ as $e: g:: f: h$ but $a: c \neq e: g$ in part as $\mathrm{b}: \mathrm{d} \neq \mathrm{f}: \mathrm{h}$ in part then $\mathrm{a}: \mathrm{c}$ can be split in $\mathrm{a}^{\prime}: \mathrm{c}^{\prime}$, which is less relevant in the relationship and $a^{\prime \prime}: c^{\prime \prime}$, which is equal to e:g. Hence e:g, being narrower, is a mediator. The same applies to $b^{\prime}: d^{\prime}$ and $b^{\prime \prime}: d^{\prime \prime}$.

The end product of real analyses should be the full explanation of a chosen myth and of all the myths within the corpus to which it belongs. Lévi-Strauss attempted this for all American Indian myths. During analysis the corpus remains openended and, besides myth, can draw in ritual, art, and all uses of signs or symbols in a given community and its historical relatives in the widest possible sense. All American Indians are relatives.

Finally, it must be stressed that there remains an absolute freedom of choice in finding and setting up oppositions and that despite the notation, symbolic logic is not strictly deductive, even after the first pairs are set up. For of necessity every symbol has a number of qualities (shape, time, color, space, quantity, odor, movement, etc.) anyone of which can serve as a basis for further oppositions, varying merely in elegance.

To illustrate these steps, I use some Kuba data.

(i) fowl: guinea fowl means bird of village : bird of bush (ethnographically attested)

(ii) goat : mbeem antelope means horned animal of village, horned animal of bush.

(ethnography supports the pair, but not as strongly as (i). hence: fow1 : guinea fow1 :: goat : mbeem

(iii) at the simplest: Antelope (mbeem) can be opposed to fow if necessary in a myth.

more complex: fowl feather : eagle feather :: masks $A+B$ means mask $C$ opposing authority in village to authority in society (each pair attested ethnographically).

then, fowl: guinea fowl : : goat : mbeem

fowl feather : eagle feather : : masks A+B : mask C. And we have a split of meaning in "fowl," where the feather matters. A whole host of possibilities now exist. If mask $C$ sports an eagle feather, there is mere equivalence. If it sports a fowl feather, it expresses the whole opposition which in the end will be nature vs. culture but here is in the avatar of superior versus inferior authority. Should we continue in the arena of feathers we could wonder what parrot:eagle feather does, or eagle:owl feathers or a dozen others, all expressed in the ethnography and--for these two pairs-also in myth. To shorten the expose--the parrot feather means illegitimate force and the owl feather the power (legitimate or not) of witchcraft. But owl: eagle can also express night:day. If the latter is chosen, eagle becomes equivalent to fowl (always a rooster!) and guinea fowl to owl. Guinea fowl is then read as "a weaker sort of witch- 
craft" of a "lesser night," for instance the night associated with the moon, while the owl's night is associated with moonless nights. If we relate all of this to kingship, we can say that kingship is superior legitimate authority, by ordinary coercive means and by the practice of witchcraft, is responsible for the life-giving qualities of the sun, etc. Some of these reasonings do occur among the Kuba and some do not.

Given the above, it is clear that some limiting rules in using analogies must exist. They are:

(i) comparison will only involve opposition.

(ii) no triads or higher order sets are allowed.

(iii) all equations must be symmetrical and greater "elegance" is reason for choosing one term over another.

(iv) no opposition or transformation is to be used that will contradict the "basic tension" uncovered.

(v) all materials must stem from a single historical whole.

By rule (i) all relationships between images (e.g., by extension, by similarity of feature, or by inclusion within a wider set) must be reduced to oppositions. Rule (ii) reduces all triads to binary sets as in $a: b: c$ set up $A:(b+c)$ and as $a$ next step b:c i.e. applying dialectics. Rule (iii) derives from rules (i) and (ii). Rule (iv) is never stated as such but is obvious. If one approach does not result in "basic tension," different choices must be made in setting up oppositions. Rules (iii) and (iv) imply that the shortest chain yielding "basic tensions" is preferable over all others. On rule (v) we already saw with Amerindians that the single historical whole may be at the most remote level.

Apart from the fact that choices are possible in considering the qualities inherent in any image, the number of choices is increased by the fact that each opposition involves four items: two signifiers (images) and two signified (meanings). Connections to other pairs can be made either through the signifiers or through the signified. Moreover, there is no rule that limits choices of images in a given myth, for example, to those that are clearly predominant in the story itself. That implies that often oppositions are not at all evident in a given myth. Take the following Kuba story. ${ }^{9}$ A king carrying his metal staff of office met a notable carrying a dead owl for his supper. The notable had earlier caused the death of the ruling queen, the king's mother. The king killed him, then, fearing retribution, hid in a marsh. But his people found him and knew he was the culprit because owl feathers still stuck to him. From that day stems the right of kings over life and death, the prohibition for them to wear this type of staff, and the prohibition for all against eating owl.

It is legitimate here to use the feather ranking in Kuba costume and oppose eagle feather:owl feather and go for a "basic tension"--that the greatest power of the king is not lawful but the most repulsive witchcraft. In doing so, we would be close to some Kuba exegesis. We could go for "divine king source of fertility and source of doom." We could contrast "wet and dry," "day and night," even "man and woman" (queen and king: one killed, 
one killer)--any image at a11 in that tale. Since analysis starts from any point in an open-ended universe, I can choose what 'fits,' and discard the rest; only my sense of dramatic effect, elegance, and creativity will then limit my scope and hence the outcome. What I might do with this myth is simply not predictable, not can it be replicated by anyone else or falsified, only faulted, perhaps on the grounds of 'lesser' elegance.

Structuralism has often been criticized most effectively by Nathhorst and there is no need to repeat this. ${ }^{10}$ Levi-Strauss simply does not follow the canons of the hypothetico-deductive method and it is impossible to connect his analysis definitely with any human condition except his own particular mind. An analysis of his first study of myth, the story of Asdiwal led critics to the conclusion that there is a lack of empirical evidence about the Tsimshian in Asdiwal, that it abounds in unwarranted generalizations, shows occasional misrepresentation of data, expounds blurred theoretical assertions (we don't know what he asserts about the data), and fails to account for the data. 11

Structuralism in any of its classic guises is not valid science since the results are neither falsifiable nor replicable; reasoning is by analogy only and aims to convince, not to prove; and analogical reasoning has nothing deductive about it. ${ }^{12}$ In addition, ethnographic validity is irrelevant for structuralists, that is, it is not necessary that anybody in that society ever thought about a myth in the way structuralists do. Finally, the conception of "the mythical mind" is metaphysical, in fact Hegelian, in nature. Grand structuralism is simply unacceptable as anthropology because of disregard for particular cultural data and unacceptable as scientific pursuit.

Yet metaphors are widely used and oppositions often occur in oral narrative and in its performance. To understand them in a valid way several criteria must be met and proven from the ethnographic record, so that replicability and falsifiability are assured. They are:

i] Analogical resoning is demonstrated to be used in the culture.

ii] Meanings offered for metaphors are emic, that is, attested by a person or persons in that culture, and the opposition must be found in a single text and not constructed.

iii] The relationship and its meaning must be shown to express a "universal" truth in the culture, that is, a truth holding for all contexts there and in the same way.

iv] Equivalences, mediations, and transformations must be shown to have been made by carriers of that culture.

v] Distinctions between symbol and reality must be kept clear. An item can merely be a symbol, as the eagle is the king of birds and symbolizes kingship. Or the connection is real. To the Kuba owls are real omens of witchcraft and not just metaphors.

vi] The precise extent of such reasoning and of the generation of symbols must be made clear. Are the data the product 
of one person's thought (albeit a person of that culture) or are they generally accepted and known?

Reading ethnographies shows that (i) seems universal and is a property of the human mind in general. But the mind does not always proceed by opposition. ${ }^{3}$ Association by inclusion (partial or total) or by partial similarity (usually of a single property, including words by which the items are designated) are prevalent in such reasoning. Emic meanings are rarely fully documented in the ethnographic record. They especially fail in documenting equivalences and transformation. No Kuba ever, I think, equated goats and roosters or opposed roosters to mbeem antelopes. The two oppositions--fowl:guinea fowl and goat:mbeem-do not occur in the same contexts and there may be a rule of closure that forbids generation of a rapprochement here. Third$1 y$, no structuralist practice takes context into account as a condition for establishing the link between image and meaning, meanings being rarely universal. In one context the kuba king is the sun, in another he is the moon. In one context he is eagle, in another fowl. Precisely because all analyses jump from one situation to the other or from one text to the other, this conditional bond between context and meaning is lost. Yet when one learns to reason by symbols and analogies or when this is taught in initiation schools or outside it, the rules of context are specified and are crucial in the generational grammar of symbolism, for symbolism is generated like discourse. The reason I have not written a symbolic structuralist account of "Kuba" thought is precisely that such rules are unpredictable from one's armchair. They must be found by generating sequences that are declared acceptable or unacceptable. Fourthly, no structuralist operation of mediation or transformation is based on what participants in the culture have themselves "transformed" or "mediated." Fifthly, often no attention is given to the difference between symbols and reality. To the Kuba the sun really gives life to everything but it is disputed whether the moon really influences the fertility of women. The rooster really calls the sun each morning, but the rooster is only a metaphor for the king, or the headman, or social order, as the case may be, in different context. To Christians the lamb of God is an image, the man Christ as God is a reality and to blur the distinction makes it impossible to understand Christianity. Lastly, metaphors, or a chain of them, can be common knowledge or the product of individual speculation. It is crucial to know which, even though structuralists never seem to bother with this question. ${ }^{14}$ Foreign researchers do not allow for the operation of metaphysical speculation in "other" communities, denying the existence of thinkers or philosophers in the ethnographic world of the "other."

By all these criteria except the first, structuralist practice fails. The basic reason is an incredibly arrogant assumption: myth is a veiled narrative that can be decoded only by foreign researchers, not by locals who have grown up in the culture studied, think in its language and metaphor, and, as thinkers 
and artists, use form and metaphor to create and perform symbolic discourse as oral or visual art. But no, the foreigner (who must be an academic) either at home or after a year or two in situ knows better. Why? Because he has access to comparative material? Hardly, if you do not believe in a single "mastermind" acting through all cultural expressions for units that may have shared some ancestors many millennia ago or even in a "mastermind" universal to all. Why then? Perhaps because academics have, so they think, mastered a way of thought that is the only access to "truth." If that is so, it is the hypothetico-deductive method. In fact structuralism is in the last resort an expression of a particularly insidious form of ethnocentrism where etic ("universally valid--and what the researcher concludes") stands against emic ("what the folk studied actually believe") and even in analogic reasoning must be superior and true. This is how Marx can be found in Fipa myth. And to stand accused by a structural anthropologist of not being one for refusing to accept such an endeavor certainly is a paradox. I5

Is structuralism useless? Why has it had such a success? Basically, structuralism is a fine tool for literary criticism, provided one accepts that it deals with the resonances a given reader can read into a text beyond the intentions of an author. To the student of another culture, however, the method's only use is as a heuristic device in the field. The fieldworker can test his hunches and reasoning (not by direct questions!) by seeking exegesis, by learning the hermeneutical skills current there, and by proposing sequences to see if they are approved or rejected. The fieldworker must Zearn to use analogical reasoning as it is practiced there, he must learn distinctions between reality and symbol, he must Zearn the rules of context that close off further deduction or deny equivalences, etc. For the historian working with oral narrative or poetry structural analyses can point to possible operations of structuring by membory or practices of composition and performance. Having checked his interpretations in this way the historian needs only to present the results: not every step of his heuristic search need be explained, just as he does not present all the red herrings he may have pursued in archives. Structuralist analysis is but a heuristic device and should be used as such.

To give an example of how to analyze a myth, I take the Kuba tale of how Mboom created the world (M 16 in the catalog by de Heusch). I follow the text given by Torday in the exposition but consider all known variants later. ${ }^{16}$ Mboom, a paleskinned giant, vomited the heavenly bodies, standing in the primeval water. The sun uncovered land as sandbank. Then Mboom vomited nine animals (variants, perhaps $2 \times 9$ ). A third time he vomited many people and one spirit Lakoyin (not, as Torday has it, a white man). The nine animals vomited the others of their speciesas Kuba rank species. The snakes vomited by the crocodile then vomited the grasshoppers and the iguana. Three persons also vomited. The first, Nyony aNgaan, vomited ants, who built the first anthill as a grave for him, for he died vomiting them. They also fetched the soil on which plants could thrive. Another 
person vomited a plant, which vomited all plants, and yet another vomited only the hawk (Dmunken King, 156-57).

We have here an orderly notion of creation. Mboom vomits three times: bodies in the sky, animals, and people. Three is a good number and three times three is perfect in all circumstances among the Kuba. Given this first creation, other beings are being produced by the ones already created and today's informant clearly had a whole Linnaean-like taxonomy of the world in mind. He speculated exactly in the same way that Kuba use genealogies to express relationships among people. Even the mention of lightning as an animal fits here because all Kuba hold that lightning really is an animal.

We can follow this thinker well enough. There is Mboom, pale like all nature spirits. Vomiting is creating. A genealogical order explains the world. There remain some oddities. Why the hawk? Why Nyony aNgaan and his death? Why the person who vomited a plant? Apart from the number three, it almost looks as though there is material here that does not derive from the taxonomy. I did not add a tail-end to the myth that explains how fire came on earth as the result of lightning's actions. That seems to be a separate epilog.

In comparing versions, it is clear that the general explanation holds. There are quarrels over the distribution of ancestors to species, the number of times Mboom vomited (often just once), etc. And the stories about Nyong aNgaan, the plants, and the hawk do not always appear. Comparative research turns up the fact that a similar account of creation by Mboom (but in what manner?) of three beings is found among the Mbole, a central Mongo group in the forest to the north of the Kuba. The name Nyony also turns up there. So does the isolated hawk. ${ }^{17}$ Nyony aNgaan occurs elsewhere among the Kuba as one-half of a mysterious Siamese twin that represents Fate. The Kuba emigrated from this area many centuries ago. And this account of creation by Mboom must be old because among them a number of animals are named as " $X$ of Mboom" even in ordinary language. Further comparison shows the story of lightning to be a separate tale, not directly linked with this myth.

So we can conclude that a notion of a creator Mboom, who produced (perhaps "vomited"?) a good number $(3,9,2 \times 9)$ of beings, existed among the Kuba. Individual speculation among the Kuba as to the nature of the world and the requirements of performance have led to different interpretations and elaborations on this theme. But the theme itself may well be very old. Examination of the variants shows first that this account of creation is the 'official' one, stamped by the seal of approval of all the separate councils of the Central Kuba groups. It is not just an item made up by Torday's informant. But it was not reported (at least in the 1950s) from the peripheral Kuba groups. And at least two informants were critical of the story on the grounds that no one could really know what had happened. This general acceptance did not prevent further speculation. Indeed there are other accounts of creation and Mboom himself is sometimes explained as the product of the original chaos (supported 
by the linguistic derivation of the term) linked to water and often seen as a marsh. ${ }^{18}$ The account of all known Kuba traditions shows that several stories of creation competed, although this was the official one and all are best explained by the known activities of speculating common among Kuba thinkers.

And at this point our interpretation must stop. We know what is common in this myth, what is variable, what is added, and have an inkling about its antiquity. Furthermore, we know that another myth, that of the creation by Ngaan, is a calque of this model. We can use the myth when studying Kuba taxonomies and this may be relevant in analyses of animal symbolism. So far at least, this interpretation, based at every point on ethnography, is replicable and falsifiable. Should I draw conclusions from details--for example, that sun created land by drying--and link that to, say, the supposedly beneficial effects of sun vs. rain in the Kuba climate, I would be speculating without the linking evidence necessary to do so.

III

Rwanda

For a number of reasons Rwanda is an excellent case by which to test in a concrete way what structuralism actually achieves. Many studies have been done; many texts have been published; de Heusch has been familiar for decades with the material and the country; and he devotes five chapters of his book to this topic. The first two analyze texts drawn from the genre of historical tales (ibiteekerezo). The published text with the liturgy of the "dynastic code"--an extraordinary body of data, so far unique in sub-Saharan Africa--is the basis for the next chapter. ${ }^{19}$ With this text we are certain that all the aspects of this sacred kingship are known, unlike the situation in most other African cases. Then de Heusch returns to the myth of Ryangombe, the hero of the imandwa cult. ${ }^{20}$ He closes his remarks with a discussion about the nature of myths that opposes him to Pierre Smith, a student of Rwandese oral narrative as art. This book within a book cannot be discussed in depth here for, as G. Dumézil, so often invoked in this volume, put it: "Having neither the time nor the taste to write the monography that would be necessary to put things right, I limit myself to a few remarks."21

Hence I discuss only the structuralist approach and 1 imit my argument to points in general. I examine successively the choices made of data, topics, symbols, and argument (i.e., the plot and the use of style as part of the argument). I then examine the whole study as a historian and conclue.

\section{Choices}

'We have used the greatest number of sources possible while avoiding arbitrarily weeding or sorting out or 
imposing a hierarchy on the data" (225).

In fact, this is not so for de Heusch has mainly used the collections of ibitéekerezo made by Pages, Coupez Kamanzi, and Smith, the latter two of which are text editions. ${ }^{22}$ He has not used the approximately ten times larger collection I prepared, nor the accounts in the various works of Alexis Kagame, although some are cited in the bibliography. Inganji Karinga, the textus princeps for many of these is not listed, nor are a host of scattered sources. ${ }^{23}$ While it is true that my collection has not been formally published, it is available in microfilm to any interested party and there is a typed copy on file at the Musée royal de 1 'Afrique centrale in Tervuren. ${ }^{24}$ Indeed while discussing genres with Smith de Heusch does not cite yet another work by Coupez and Kamanzi that covers exactly the same ground, so even a11 printed works are not included. ${ }^{25}$ If he had used my collection the different versions of the Ryangombe tales would have precluded his setting up Myth 46 (200-02) since there is a whole cycle of takes involved here.

Another choice is in fact to determine what a myth is. De Heusch calls a text a myth and gives it a number as well as a title. Myths are summarized in his presentation, so once again there is a choice as to what he retains and what he omits and we never learn what his guiding principles are when he lumps or splits. In practice he usually goes by the printed text, actually those of Coupez/Kamanzi (M 34, 35, 36, 35bis, 37, 38, 40, 36 bis, 36 ter, 44, 46, 47) or, when they lack the tale, Pages (M 38 bis, 39, 41, 42, 44, 45). Smith occurs twice (M 34, 46) and only once (M 46) does de Heusch use multiple variants.

Coupez/Kamanzi, however, printed the performances of but a single informant, Gakaniisha so that in effect this man's approach to a large extent conditions the foundations for the analysis of de Heusch. This is not a mere quibble, for it is quite characteristic of de Heusch to give an "explication de texte" drawn from a single major text elsewhere as well. Thus H.A. Junod, Moeurs et coutumes des Bantous (Paris, 1936) is the text underlying chapters 10 and 11, Hilda Kuper's various writings about the nowaza for chapter 7, and texts from an anthology of Leo Frobenius for chapter 8 .

A further choice was already made when de Heusch limited his material to ibitéekerezo and the royal genealogy, one apologue (75), and the texts of the royal ritual. He chose not to make use of poetry of any kind or of other literary materials such as proverbs to help him elucidate meanings. Yet the genre of dynastic poetry is directly relevant here, especially because it shows which metaphors and trains of metaphors cluster around various kings and kingship and how imagery is used to structure metaphor.

Yet another choice occurs when de Heusch arbitrarily excludes all historical tales after the reign of Mutára Séemugeshi, claiming that with this king a "historical" period actually begins. While he concedes elsewhere (354) that the distinction between "mythical" and "historical" tales is artificial, he still 
maintains this division, invoking the authority of Dumézil, who had distinguished what was "mythical" in Rome's history (the first three kings) from that which was historical. Granted, de Heusch continues, that in societies without writing this is more difficult to do, nevertheless in Rwanda the mythical fresco concludes with Ruganzu Ndóori (in fact he actually concludes with the next reign). He also chooses to exclude several of the kings, namely those who follow the first king who fell from heaven and king Gihánga's immediate successors. We do not have much more than their names $(48-49)$ from the official genealogy. ${ }^{26}$ But these names have meanings and their succession makes clear that some account about the origin of the world is involved. ${ }^{27}$ In translation we have in succession:

a] "The fallen ones" (ibimanuk $\alpha$ ) or "the path to..." (implied Creator)

Thunder

The One Who Came Down

Man

The Fallen One

The one from Heaven

The Hole (probably in the vault of heaven)

Seed

Creeping like Vine

Void

Prohibition

Sma11 Root

b] "Kings of the Belt"

The Creator

Kanyarwanda Gahima (eponym for Rwanda and ethnic name Hima)

Yuhi Musindi (eponym of the abasindi, the royal descent 1ine)

Who Makes Sprout

Master of Dew

Big Boat (or "narrow place containing many people")

Crowd

Ndahiro the Flowering

The Fishing

Samembe

Nsoro the Nave1, whose secret name is "the Hunter."

It is not difficult at all to handle $a$ and $b$ as corresponding parts of a single set as for some names; in the form of a riddle this works very well. Thus-- Who Makes Sprout?--Seed. What does Master of Dew do?-Creeping like Vine. One the face of it this is splendid material for the structuralist. Yet de Heusch does not use these data, no doubt mainly because no texts are associated with them. For he does use these names that are mentioned in tales.

A further choice that seems arbitrary is to deal with the Rwandan data in splendid isolation. One would expect that he would compare these tales with other materials from the interla- 
custrine areas rather than to compare them first with Luba or Swazi myths. But he doesn't, even when there are palpable indications. The finding of the dynastic drum in a milieu of vines (61) is found in Burundi while the tales about pythons $(62,84)$ recall the belief in Burundi of rebirth as a python. ${ }^{28}$ Topics such as the Hunter--or rather the Foreigner--founding a kingdom are found elsewhere and again in Burundi (Ntare Rushatsi, "the disheveled"). Even when he deals with Ryangombe, which is the local metamorphosis of the Cwezi cult, he gives only one comparative myth (214) from Buhaya, but nothing from the voluminous literature from Uganda or even others from Buhaya. Nor are any myths from the western ighbors of Rwanda introduced at al1. Less obvious choices, but choices nevertheless, occur whenever comparisons are made. Possibly this may be but the residue of a much larger number of comparisons from which only those that led to "results" were included. Still, when one steps outside Rwanda (as on 220) to compare the succession of the Founder-Hunter-King with the Warrior-Hero-King, it strains one's credulity that only Rwanda and Luba would count. By extending "Hunter" to "Foreigner" the succession of the Kuba kings Shyaam and Mboong aleeng would fit very well. In fact in any number of cases one finds ideal figures of a Founder-Stranger and later of a WarriorHero type.

Within the Rwandan corpus certain comparisons are not made such as one between lizard and toad. The lizard (76) sens urine in the eye of Lightning, allowing Death to escape. Toad quarrels with Lightning over a pruning knife (52-53) but they resolve their argument and in certain versions became blood-brothers. ${ }^{29}$ Smith pointed out that lightning is a fire in the middle of water and moves fast while Toad to Rwandans also is dry, smoking his pipe in the water, and cannot move, but is everywhere (in folktales). Toad is the totem for the three clans into which later kings of Rwanda married. An inverse relationship between Lizard and Toad would show:

\section{Lizard: 1ives in sun (heat) expels water (urine) opposed to Heaven \\ Toad: lives in water expels "fire" (the pipe) mediates between Heaven and Earth enemy of kings blood-brother to kings}

The mediating aspect is cited by de Heusch (108), who also equates Lightning and Heaven, which the Rwandese do not do. He recalls that Lightning is in fact Thunder, the origin of everything but we do not know whether or not Rwandese make this link. After all, by his standards this could have been included and the blood-brotherhood could have been linked to the dynastic marriages and to fertility while Lizard, the ally of Death, might have been linked to some negative flgure--enemles of the kings. Ideally every point of comparison in his Rwandan corpus should have been made between one myth and all others. De Heusch does make a great number of comparisons, but achieves only a portion of all possible comparisons. How then does he choose? I will 
return to the question later.

There is also the choice made of oppositions to be stressed. By their very nature symbols have more than one characteristic. In any case we find parallelism exploited, rather than strictly logical oppositions. ${ }^{30}$ De Heusch tells us (43) how complicated in fact simple-looking propositions actually are. There we are givèn:

Kigwa: born without a celestial umbilical cord. Bwimba: rejects his terrestrial umbilical cord symbolically. Kigwa: his sister falls to earth with him and marries him. Bwimba: his sister lets herself fall from up to down (sic!) to join her brother in death.

We understand that Kigwa was born in heaven within a sacrificial cow's heart fed with milk (32); no umbilical cord is mentioned at all. ${ }^{31}$ We also understand that Bwimba's mother tried to stop him from going to his death by putting her belt across the entrance to the compound. He stepped over it, thereby breaking the prohibition to do so. ${ }^{32}$ De Heusch, 1 ike Smith, supposes that the belt stands for an umbilical cord. ${ }^{3}$ So in the first element of the comparison there is already one substitution worked in and it is assumed that somehow the absence of an umbilical cord and the celestial/terrestrial opposition would be grasped, however implicit and accidental they are in Kigwa's tale, where milk and cows are the palpable symbols.

For the second element we understand that Bwimba's sister Robwe threw herself from a partition unto a royal drum and that she and her unborn child died (42). But the full text makes clear that she did this in a rage, so that there would be no heir to the throne of Gisaka. ${ }^{34}$ In falling she broke into two parts. Everyone in Rwanda knows that a dynastic drum stands for a particular kingdom, but this was not a dynastic drum. If it had been, Gisaka's drum would have conquered the sister of the king of Rwanda just as her husband, the king of Gisaka, had killed her brother, the king of Rwanda! De Heusch, however, equates the drum, an ordinary royal drum, with the dynastic one. In doing so, he changes the symbolism of this tale, which is that revenge for the brother's death was the death of the king of Gisaka's heir. His summary here reverses the meaning of the tale. Even corrected, though, Robwé had to climb on something to fall, to throw herself to death on a drum; falling necessarily implies this. In Kigwa's case not much is made at all of falling. ${ }^{35}$ The text used by de Heusch has Kigwa (alias Sabizeze) tell his brother Mutuutsi: "Let us go also with our sister, let us leave for another land." The sister is merely needed for reproduction, just as they propose to take a rooster and a hen, a ram and a ewe, a bull and a cow, and a heron (of which only one is mentioned). So here the falling is unimportant for Kigwa's sister and crucial to Bwimba's sister. It is only by ingenious contrivance that these sets of similarities and oppositions have been concocted and they leave the obvious major intentions of either myth aside. The choice is foisted onto the data. 
This one example can suffice to show how every similar proposition advanced in this book requires careful scrutiny and that the relevant data are not always clear from the text. To round this off, Kigwa (46) brought with him the sacrificial animals used in divination (cattle, sheep, poultry), thus introducing the divinatory function of kingship. Bwimba introduced the self-immolation function of kingship by his death. Moreover, Kigwa is born from an act of sacrifice (the heart of the animal killed) whereas Bwimba dies in an act of sacrifice. This last proposition does correspond to the major intent of these myths. The first is elegant but does not fit, for Kigwa not only brought divinatory animals, he also brought the white heron inyange. On1y by omitting this will the first proposition fit neatly. It is quite arbitrary then to stress this "divinatory" function.

Choices of oppositions can go to greater extremes of artificial manipulation. On pp. 140-43 de Heusch splits Ruganzu Ndoori into Ruganzu A and Ruganzu B for purposes of comparison. On 85 the Luba figure of a python corresponds to a series of complementary representations of the actors Nkongoro (similarity of name), Nsibura, and a python. A tortuous explanation shows how. Obviously with such a method it becomes impossible to have accidental resemblances, not matter what is compared to what. An excess of flexibility kills credibility--to oppose two 'ibility' terms...

Myth in Rwanda: the Argument

Like al1 books, Rois nés revolves around a set of chosen topics and problems. Here they are the structural analysis of a corpus of Rwandan myth with the goal of clarifying their inner meaning. But first, what is a myth? Not all tales are myth. The cycle of Kagoro in Rwanda is excluded: it is a novel ("roman") while M 47 (207-09) is said to illustrate how mythical thought runs out of breath and turns into a novel (cf. 224). Had de Heusch consulted the versions of his corpus as narrated by Mugina, his remarks would be even more apposite. Mugina is a master teller and his tales range anywhere from two to four hours and sometimes more. What de Heusch calles "romanesque" are in part the effects of a good performer's craft. This is why precisely a comparison of many variants, rather than a single basic "text," would have given a better feeling in each case of what the myth actually 'is.' We also saw that not all historical tales are myth in practice; only those that deal with early kings are.

In his discussion of myth in chapter 6 de Heusch acknowledges with Smith that myth is not a genre in Rwandan 1iterature. ${ }^{36}$ But he vehemently rejects the idea that structuralism applies to all genres and reveals a mode of thought valid in literature and religion. Rather, he claims, there is something that is not just a tale--an epic tale, a fantastic tale--but a myth. And he calls on Lévi-Strauss (240-41) to settle the issue. 
The master assures us first that "almost all" societies distinguish between myth and tale--just the kind of flat decree that rings false. Then we are told that myth has (a) more logical coherence; (b), is more strictly subjected to religious orthodoxy; and (c), is more subject to collective pressure. What criteria! The first is in the eye of the beholder: what 'works' is myth. The second makes no sense in African contexts where oral societies do not stress dogma nearly as muchi as participation in common ritual. And how, in any case, are we to measure all three?

Myth is not a genre. To de Heusch mythical thought lodges itself preferentially in historical tales, thus unveiling its own finality: to establish the sacrality of "le pouvoir" (241). Note that mythical thought is an actor and expresses a position that is idealistic, quite in line with Lévi-Strauss himself. ${ }^{37}$ Myth proposes a transcendant truth and expresses it first of all in the major genre where the real destiny of man is at stake: historical tales (241). In short myths are narratives believed to be true and purporting to be history. Their goal is to establish the sacred character of government. In Rwanda myth is encrusted in dynastic history, be it in its popular or in its esoteric face (242). And myth is reified as in: "the systematic labors of mythical thought" (155). De Heusch is unique in linking myth to sacred kingship so that where there are no kingdoms, there can be no myth (234-35). Too bad for the Fang, Mongo, and Nyanga cited there. In keeping with this view, fantastic legend derives from religious legend (232) and we saw that "novels" are myths run out of steam.

Within this arena the goal is to show how myth validates the various functions of Rwandan kingship. These are five: divinatory, self-sacrificial, productive, military (including magical), and legal $(90,97,110)$. Pierre Smith has found two functions, however: sacred and secular. ${ }^{38}$ Such functions are ideological in the formation of a theory of kingship. Both authors derive this concept from Dumézil, whose crucial insight (which de Heusch accepts) was to see that all Indo-Europeans shared the notion of three functions (sovereignty, war, production). ${ }^{39}$ These are then proto-Indo European for him. De Heusch split sovereignty into three, but so far unlike Dumézil, he does not attempt to find them at proto-Bantu levels. He merely concludes (243) that "Bantu myths...convey singularly constant symbolic systems of a cosmological and ideological order." One day perhaps that "ideology" may be presented to us as the five functions.

It would be wrong to state that the clarification of these functions is the only goal of the Rwandan study here. Chapter 4 shows how functions are associated with the four cyclical dynastic names (156). Chapter 5 essentially contrasts the ideology of sacred kingship with mystical counter-kingship (210-13, 220). The functions are not expounded much in the conclusion to this part of the book though in fact there is no proper conclusion, unless it be that Bantu civilizations are unlike west African ones in being less concerned with the creation of the universe 
and more in the adventures of kings (242-43). Readers should realize that such a situation is typical for structuralist studies. They are rather like the tapestry of Penelope; they are never done since one can always find new strands. And so is the zig-zagging of the argument with its countless interruptions.

Given this view of myth, how does de Heusch choose particular symbols or topics rather than others? Obviously, anything that is a symbolic expression of kingship, such as the dynastic drum, is to be inlcuded. But it does not take long to discover that the features dear to Lévi-Strauss in Mythologiques are also present in both The Drunken King and here. The raw and the cooked, the honey and tobacco, noise and silence--to mention only a few colorful and obvious ones. Some, such as silence and noise are justified in part by the rules about beating drums and the use of rattles in liturgy. Honey and tobacco, however, are much less evident and presumably would not have been noticed were it not for Lévi-Strauss. Just as the "functions" derive from Dumezil, at least one, and probably more, topics also derive from him--for instance, one-eyed and one-armed men (75-80). A direct parallel is drawn here between Indo-European heroes, whose strength is multiplied when they lose an eye, and an episode in the story of Ruganzu Ndoori. He is of the stripe of Odin or Horatius Cocles but we are not told how to account for this surprising resemblance. Again without effort I can think of a Kuba parallel where the warrior king Mboong aLeeng was wounded in the eye and died as Ruganzu did, though we have no increased strength here.

A full 1isting of the topics pursued, let alone a full discussion, would take us too far. Suffice it to say that they are neither all the possible ones in his corpus, nor are they all tailored simply to carry an argument forward. They are an amalgam familiar from earlier work on sacred kingship; from earlier structuralist writings, including De Heusch's own; from a few Dumezil topics; and even a few from the dominant oppositions made within tales of the present corpus. In this very real sense this book continues the discourse of Lévi-Strauss and of The Drunken King.

The discussion about Rwandan myth is hard to summarize. At times there seems to be no overall argument at all. Chapters 2 and 3 comment on the corpus of myth, chapter 4 comments on the royal ritual, chapter 5 deals with Ryangombe (not a king), and chapter 6 is an interlude to argue with Smith. The main discussion in chapter two turns on the matrimonial code of the dynasty and its divinatory and sacrificial functions. The next chapter develops all the functions and returns to matrimonial questions but it is impossible to discern why this point or that one precedes or follows others; even de Heusch is aware of the confusion he creates (86). All these symbolic themes chase each other endlessly, crossing and criss-crossing like elements in a fugue-but an open ended fugue, there are no organ points. In his frustration the critic suspects that without clear conclusions there can be no clear argument. What does this mythical corpus actually reveal when decoded: the functions of kingship? Is all the rest just "noise"? But even such functions do not lead us far beyond 
the paradigmatic ideals of different kingships succeeding each other in a set cycle. D'Hertefelt and Coupez' publication of the royal ritual and their annotations already achieved that. Is there more here? Perhaps, but I only find chips: provocative explanations of details strewn about haphazardly. But alas, the more provocative, the more contrived, the less convincing.

The invocation of the technique of transformation in all of this becomes a true deus ex machina, even when it looks simple. Thus (88) the Renge story of the construction of a tower to reach heaven and its collapse--the tower of Babel motif--well-known from central Africa is said to be the transformation of the image of the rainbow. ${ }^{40}$ No trace of rainbow in these tales...but wait! In one version the fall of the Renge was due to a Mashirá, master of the rain. "Hence the myth of the Renge is but a variant-probably a very old one--of a cosmogonic myth widespread in Central Africa" (88). We must turn to 74 The Drunken King to explain how that transformation actually occurs. It rests on the parallel between the Tower of Babel story and the fate of one or two signal drummers remaining high in a tree to warn the Luba hero-king Kalala Ilunga. In some variants they die. Kalala was later to return and kill Nkongolo, the first Luban king, whose name means "rainbow." Now we have a connection:

(a) immortality - cosmic tower (tower of Babel myth) dry season lasts - rainbow, tree/tower (Luba imperial myth)

(b) death introduced - tower destroyed (tower of Babel myth) dialectic of the seasons - rainbow beheaded (Luba imperial myth).

There are you--rainbow is tower. The sequence of assumed equivalences in a number of myths become a tower of suppositions themselves. Devil's advocates might turn to M 56 (329-30); no tower but a tree in the original) where

(b) death introduced - tower grows (Shona myth)

which contradicts the above. But de Heusch stands ready (367): "Once more Karanga and Luba myths stand in a relationship of transformation" as an inversion parallel to other inversions such as a transformation cited on 364-65. Every time the word "transformation" crops up in this work (e.g. 70-71; 335) similar icebergs of arguments are used. This, of course, makes any falsification impossible. Two items are either parallel or they are not. If parallel, they are either the "same" or "contradictory." If the latter an inversion has occurred and they are still the "same"; if not parallel, they are not compared and irrelevant.

Manner of presentation is always important, especially for de Heusch, because the style of expression plays a heavy role in attempting to convince the reader. Thus his range of expressions to denote "of course," "obviously," or "no doubt" is far richer than usual. Without being exhaustive, the following struck my eye: the austere "assurément" (295, 422, 450) or "il est évident" (328) or "évidemment" (330); the assertive "on ne peut douter" 
(85, 327) or "il n'est pas douteux" (240); the inventive "tout se passe comme si" $(26,85,322,350,455,459)$; the reasonable "selon toute vraisemblance" (30); the persuasive "il est aisé de comprendre" (33), "hous avons quelque raison de croire" (38), "tout porte à croire" $(313,470)$, "il est clair que" (385), or "on ne peut s'empêcher de" $(305,350)$. Other variants are "il ne fait pas de doute" (263) and "on ne peut douter" (85, 301). "L'on comprend aisément" (306) is positive and "on n'échappe pas à la conclusion que" (335) fatalistic. The "admettons" (294) is very nice since it claims that the Swazi and Rwanda share a close historical kinship. Such formulas, taking the place of real argument, merely avoid proof. They recall the jingle

\section{"O, let us never, never doubt \\ what nobody is sure about." 41}

Apart from this technique, authorities are called on in debate with other scholars or just so, as the references in the index to Lévi-Strauss and Dumézil testify. At 1ast, quite elegant, ploy is to state that, in effect, "I am the first to agree about $x$, but nevertheless, $x$ is so." Who can be faulted on such dialectics. Thus on 236: "It would be foolhardy to reconstruct a history of oral literature on purely conjectural bases. Nevertheless..." or (219): "This structural kinship certainly poses a historical problem. We do not pretend to solve it. Nevertheless, two observations..." We learn that ritual is not just an illustration of myth but... $(8,155)$; that a simple opposition of myth and tale is out of the question, but... (240); that all historical tales are myth, but...(354).

The rules of method and validity

Validity must start with the quality of the sources and the assumptions made about the pertinent historical framework. And that is validity not only for a historian, but for all. De Heusch does not worry about the canons of method. He takes his texts, invents titles for them, summarizes them for citation, and references them to publications without citing the name of the performers who told them or telling us whether the texts were put on tape or retold by the narrator (as in Pagès). He is not concerned with the precise place of recording or the precise origin of the performer and does not distinguish what comes from northwest Rwanda near lake Kivu (much in Pagès), what stems from south-central Rwanda (e.g. Gakanyíisha), or northeast central Rwanda (much in Kagame), etc. No date or recording, no circumstances of performance worry him. He shows in the Rwanda section a minimal concern for literary genre, but not elsewhere. He does not think of questions specific to the dynastic genealogy as opposed to historical legend or to the ritual esoteric text and he does not care about dynastic poetry, despite its value in showing how Rwandans have read symbols and symbolic chains into their own historical tales. The notion of text is reduced to the 
choice of a single variant, all variants being on a single plane, rather than dealing with all variants since they are, after all, part of the same myth. Indeed by axiom all tales are part of a single myth. He could have worried about the question of whether all variants had been recorded or not, but he does not. He asserts that $A$ is a "popular" version and $B$ is an "esoteric" version, but he never probes the meaning of these terms. We know that certain tales such as those about Ruganzu are much more widespread and frequent than others, even though these others are still "popular," and that esoteric material only rarely comes in the shape of ibitéekerezo, and more often as short comments about popular tales. Although myths are to be the symbolic structure of kingship, de Heusch does not bother with their practical uses. Ndahiro may have succumbed to a Hutu revolt, but this is only one version, from the early 1950s when tensions ran very high. Is this detail in other variants? How do myths legitimize concrete social situations? How do they change as these change? Who quotes what in their defense? These questions are never posed and hence never answered. Instead, de Heusch stide-steps them and goes faster.

A search for the relevant information, even if limited to publications, takes time and a thorough study takes many years. De Heusch pays the penalty for his shortcuts and so does the reader, who has to work very hard if he wants to use the book. Even in the case of Rwanda, with which de Heusch is so familiar, the reader must beware. He must always consult the original texts, rather than de Heusch's summaries. He must read all the published data on literary genres, he must track down the original authors and, where useful, their biographies, which sometimes reveal quite a bit of bias. In short the research is left to the reader, before he can reach an opinion as to the validity of any point made by the author, or, taking it back a step, the validity of any of the data used in making points.

The reader would like to know to what extent the "meanings" elicited are those of de Heusch alone and to what extent the Rwandans had already found these. Rois nés almost never tells him. Anyone familiar with Rwanda who has the d'Hertefelt and Coupez volume at hand can do this to a certain extent. Beyond that, the question can only be resolved by research. Moreover, if all the ibitéekerezo are a seamless web of myth, all of the tales concerning later kings must be drawn into the study. So the Rwanda chapters of this volume are at best a workbook.

The historical background sketched or assumed by de Heusch on the whole betrays a static view of the past. The introductory sketch of a traditional Rwanda (29-31) is an example. Social categories and institutions alike are frozen in an indefinite past, although we are told--but on what authority?--that the Tutsi were there in the thirteenth century. Clientship contracts have been unchanging for ages. Clans and lineages and ethnic groups are perennial entities, never changing in composition, structure, and yes, functions, even if the Rwanda state developed in the same milieu. ${ }^{42}$ In fact, none of this can be assumed. 
For de Heusch political history and a history of ideas perform on an unchanging stage. There are no allowances for a history of institutions, a social history, a history of production, demography, etc. We are told for example that among the Swazi "clan organization better resisted the installation of a central power backed by a strong military organization based on age classes than in Rwanda" (244). That assumes that Swazi "clans" (whatever they might be...) have always been equal to themselves, like rocks overrun or not by the foaming sea of the state.

Neither the creation of the state nor of the age classes altered them. One would rather assume the contrary. The most fatal assumption is the unquestioning allegiance to the dichotomy state/"1ineage" society, so that myths worthy of the name occur only in states. The dichotomy is false so that anything based on it is false.

But the strangest of de Heusch's assumptions is in the matter of regicide and long or short life. As kingship is regulated by a symbolic structure, regicide must exist (161-65), even if it does not happen to be mentioned in the royal rituals. And bearers of certain dynastic names must be short-lived. He admits coincidence (164) when the symbolic characteristics for a given dynastic name (an eclipse, an early death) occurred in 1896 as they supposedly had before, in ca. 1792. "But," he goes on, and ends by arguing that anyone with that name must die early under the sign of a solar eclipse, real or imaginary. He admits historical accident (162) but in effect sees regicide being used as a means to conform to symbolic expectations: short reign/long reign. The point is capital. If kingship is subject to the laws of "a structural history," it should be real, it should have an impact on real events. And being king means to play out a ritual career that unfolds like a minuet.

Specific historical sketches such as the one accounting for the Bantu-speakers of southeastern Africa (306) suffer from insufficient information. In this case a few pages in an alreadyoutdated anthropological study suffice. There is no reference to recent archeological evidence or to historical studies in the area. So here are "Hottentot" and "Bushmen" followed by Sotho and Tswana, followed in turn by a double-pronged invasion of Nguni and Karanga (Lovedu and Venda), who were both carriers of sacred kingship. The ethnic groups are mentioned as if they were fully constituted since the dawn of time. The succession of migratory movements does not accord with archeological data at a11. Sacred kingship is apparently an unchanging jewel, a package that belongs to the two last prongs but not to earlier ones. No reader should accept this, but should turn to one or more recent archeological accounts. ${ }^{43}$ Sacred kingship most likely developed at $\mathrm{K} 2$ and fully at Mapungubwe, perhaps since the onset of our millennium. Given known later interactions in the Limpopo river basin, both north and south, from the seventeenth century, one cannot assume, as de Heusch does, that Venda and Karanga myths can be simply compared in order to unveil something like a "proto-myth," an assumption of chapter 8 . 
In the same example one can see the absence of chronological rigor. We are told that the symbolism of kingship among the Swazi, Venda, and Lovedu developed more or less at the same time in southeastern Africa. With regard to the known history of these peoples that "more or less at the same time" starts ca. $1000 \mathrm{~A} . \mathrm{D}$, at the Limpopo and in eighteenth century among the Swazi (244)!

Some might say: after all, de Heusch is not a historian and some indulgence is in order here. But it is not. This topic presupposes historical situations and hence that aspect should have been researched thoroughly. As noted, the general points made about validity of data apply to all.

The author's indifference to history harms him. He sees its results as a set of absolute truths or at least he is indifferent to their reliability. A good example is his kinglist of Rwanda (48-49) that he copies from an article of Smith published in 1970 that itself derived from earlier sources, dating from 1959 and 1962. ${ }^{44}$ Since then Rennie and Van Noten have contributed to this problem. ${ }^{45}$ The latter's archeological results, unlike the speculations of Rennie, lead to serious reservations as to the existing chronologies, even for relatively recent times.

More surprisingly, de Heusch acts as if the history and myth that derived from the same body of tales have no connection whatever. This is unfortunate because he does not examine the type of connection historians have proposed, namely, the crucial role of metaphor-clichés. ${ }^{46}$ That view holds that a certain metaphor always implies an identical reality. Lunda marriage in history is the subjection of the group called the "wife" by the group of the "husband." De Heusch merely accepts the interpretations for some clichés in one place (95, 97), rejects them elsewhere (164), and adds that such an interpretation is insufficient because one must show how the metaphor chosen fits into the whole symbolic structure in which it is embedded (97). For him mythical thought works systematically (155) and is a reified mastermind. This is evident when he argues that a certain king implemented cyclical kingship and its symbolic paradigms after long "premeditated labor" (154). This is pure Hege1ianism.

In practice, little attention is given to such metaphors. The most telling case is his failure to compare M 39 (66) and M 36bis (91-93) as well as M 36ter (98-99). (The "bis" and "ter," by the way, to not refer to variants but to different tales a1together). All these cases involve foreign mothers of kings. Should we accept that a foreign mother means a foreign dynastic takeover? If so, taking other signs of foreign involvement into account, the history of early Rwanda is transformed as the metaphor plays a role in tales about Ruganzu Bwimba, Kigeri Mukobánya, Mibáumbwe Mutabaazi, Yuhi Gahimá, and Ruganzu Ndóori. In this scenario we see a tiny Rwandan chiefdom, first defeated by Gisaka, then taken over by a Bugeseran line, then devasted by a Nyoro invasion, but succeeding in a partial conquest of Nduga, only to lose the old Rwanda. Then follows a takeover by a new 
Iine in the old Rwanda, followed by strife between Nduga and old Rwanda (151), then a takeover of Nduga by a prince from near lake Kivu (66), ending with the conquest and unification by Ndoori of both old Rwanda and Nduga, and no more foreign marriages after that. Rwanda is but a principality tossed about between stronger neighbors, without any dynastic continuity and certainly without a unique and highly-developed politico-symbolic structure different from others around it.

But de Heusch does not compare. He does not see this metaphor, even though he discusses the "matrimonial code" extensively $(43-45,66-68,91-93,98-109,132-34,148-51)$. Had he connected the kinglist and substantive history with his research, he could not have missed such a prominent and often repeated metaphor. It should be noted, though, that perhaps this metaphor need not always imply a foreign takeover and Miller's implicit axiom that such figures always carry the same meaning mechanically cannot be upheld. Here de Heusch is right, just as he is when he asks for eventual links between such metaphors and wider symbolic coherence, if that is present.

So, paradoxically de Heusch is far too trusting about Rwandan history. This flows from his lack of interest in history, mesmerized as he is by the continuities in the working of the mythical mind. On occasion this mania leads to extreme statements as in: "The sacrifice of Bwimba forces history, which he inaugurates, to acquire meaning in the matrix of the myth of origin." (47). Even the context (46-50) does not throw any 1 ight on the enigma. Nor can I.

"Explication de texte": an Artist Comments on this Oeuvre

The tales from Rwanda in the corpus created by de Heusch have become his own text. He has chosen his text and interpreted it by choosing his own images, oppositions, and transformations by almost free association. His interpretations are not bound by ethnography, nor does he care whether Rwandans see this point or that one. No wonder that he complains about the airy scepticism of an "almost Voltairian" Tutsi aristocracy (242). The structuralist manner, and he is a paragon in its use, chooses so much so arbitrarily that no results can ever be replicated or falsified and thereby validated.

This is all too similar to the effusions of European art critics reading their own notions into classical African art. Such critics have appropriated for their own culture what comes from a foreign environment and treat such works of art as if contemporary European artists had fashioned them. Structuralism is in part literary critique. De Heusch tells us what he can read in his text. He has appropriated the materials. This study, supposedly about Rwanda, is a text created by de Heusch and interpreted by him. He is the mastermind at work. His is the deIusion when he attributes the entrancing parallels he creates to a Hegelian Geist out there, not recognizing his own image. But, unlike with art critics, the work discussed here is a work of art 
created by the critic. For, wherever there is form and metaphor there is art. ${ }^{47}$ The tales, even as recorded, were Rwandan art but, being built up into a text, de Heusch has lifted them from their ethnographic bedrock. He has chosen pieces from an art work and used them for his own creation.

The reader very much needs to keep this in mind, lest he remain as puzzled as the gentle critics of The Drunken King have been. Attracted and entranced, they have ascribed their fascination to some scholarly virtue. They did not realize that these are the virtues of art. Structural analysis sets up its own prose poetry from the debris of tales that are true art in their own context, then imposes a new form (its own rules) on the metaphors chosen, thereby creating a new art.

Any Rwandan, any student of Rwanda, reading this book soon realizes there must be a veil here. The veil is in the pretense that this is about Rwanda rather than using Rwanda simply as a setting. The deception lies in presenting this contemporary work of art as a study of symbolic ethnography. Not that it is useless to ethnographers--by unraveling this tapestry and by fitting each thread into its own cloth, perspective can be gained. Some of the rapprochements suggested may well be fruitful for further inquiry in the field itself. Some may uncover genuine Rwandan metaphors and others may show effects of mnemonic structuring. Most parallels, however, and all transformations will remain as the vision of a gifted and inspired artist.

Rites of Passage and History

Chapters 10 and 11 discuss rites of passage, mainly among the Thonga, especially boys' initiation rituals, and move on to link these institutions in southeastern Africa to their counterparts of the southern savanna of central Africa, claiming that the latter were imported there by the Kololo.

Chapter 10, the most cohesive in the book, uses Junrod's account to develop the oppositions in ritual of "hot and cool" or "the raw and the cooked" and claims: that by itself this constitutes a cosmology. ${ }^{48}$ Yet it is not free from the typical characteristics of structuralism that have been described above. Chapter 11 shows them in a form even more exaggerated, as the Rwandan material did, because the comparisons roam further afield. Junod is de Heusch's "text," freely interpreted; the topics are familiar from Lévi-Strauss; the typical formulas of style abound; the comparative material is not really thorough; and the citations are often defective--one (428) is quite corrupt. ${ }^{49}$ The textual quote there is part of an original Thonga text of which the following lines are paraphrased earlier on (421-22), while the last line of the Thonga text is given as an interpretation of Junod that elephant represents the wealth that will accrue from the sale of his tusks. ${ }^{50}$

But the historical hypothesis is novel and requires discus- 
sion. First, it is said that boys' initiation rituals are ancient among the Sotho-Tswana and have been borrowed from them by the Thonga and Venda. This is supported in a page (416-417), citing Junod and Stayt but without listing their evidence, let alone further data. ${ }^{51}$ The assertion of both these authors that the Lemba introduced the rites some time before the nineteenth century is airily rejected. The Lemba are characterized as "a mysterious Bantu people." Not so, and thanks to Beach there is no more doubt that they were Muslim Shona who arrived as refugees south of the Limpopo from the seventeenth century. ${ }^{52}$ As Muslims they certainly circumcised their boys, which neither Venda nor Thonga did. They may well have introduced this practice, even among the Sotho-Tswana. The latter, however, probably had developed initiation rituals on their own. The Shona have none, so the Lemba probably did not have any.

The Thonga and Venda borrowed their ritual from Sotho groups (probably Pedi first) as Junod claimed, showing how the easternmost Thonga of the Spelonken area were initiated in Pedi camps, although his evidence was tenuous. ${ }^{3}$ Other data from the Zoutpansberg area, where Tsonga came as hunters for the Boers and mixed with southern Venda in the 1860s, throws some light on the question. Makhado, a Venda noble, overthrew a chieftaincy in 1864 with the backing of both Venda commoners and Tsonga, who had been initiated with him at a time when it was against al1 established usage for Venda noblemen to be initiated at a11. ${ }^{54}$ Clearly, in the troubled years of the Mfecane, initiations leading to regimentation were highly important all over the area and a spread to both Thonga and Venda is likely. A diligent historian will certainly throw more light on this question; the point is that de Heusch should have given us solid evidence. He did not because the matter seemed unimportant.

Nor does he dwell on the fact that the extant descriptions stem mainly from Thonga camps, with only the tiniest wisp about Pedi practices. Core rituals and teaching among the Sotho and Tswana still remain secret today and unknown to academics. So the derived Thonga and Venda data have to stand in for the originals, and doing so requires a defense. One must show that the Thonga rites are typical for the Sotho-Tswana in general. "Typical" involves further problems. Even in a single community there will be variability in performance between one initiation and the next since these were not unchanging liturgies. What was the variability in a given community? What was "typical" when, and for whom? The reader will notice obvious differences in the reports about different occasions. Furthermore, it is evident--and Junod was aware of it--that even the Thonga data are quite fragmentary, and Junod was much more tentative and reserved in his interpretations than de Heusch would be $(428,432)$. De Heusch does not in fact succeed in giving a comprehensive view of the main meaning of the rituals and tells us nothing about the teaching in such schools. The Sotho-Tswana cosmology remains a secret so his parallels with central African initiation rituals remain valueless-he is forced to read central African meanings into fragmentary 
southeast African data.

But these parallels are the spark (450) which pushes him to claim that circumcision rituals of the type called mikanda in central Africa were introduced there by the Kololo (464-73). Before ca. 1840 masked performances existed in central Angola and were associated with chieftaincy, not initiation (473-76). De Heusch feels that there should be a connection in any case because his map of initiation rituals in the Bantu world (map 5 and 465), after excluding initiation among the Lega, left only one block of collective initiation, the mikanda block. For him indeed proof of the recency of the diffusion was the use of the single term mukanda everywhere (472) to designate it.

The hypothesis fails. Central African mikanda rituals are not derived from southeast African models. A glance at the map by Baumann shows that there were more complexes of boys' initiation than de Heusch allows for. ${ }^{55}$ Apart from the disputed cases of Mozambique and southern Tanzania (465: individual only? collective?) the Lega case is only a small part of a distribution that includes the whole of Maniema up to and beyond Kisangani, a complex as "Bantu" as any other. Other complexes among Bantu speakers occur in Gabon south of the ogowe river and in southcentral Cameroun among the Fang, Beti, and Bulu. So there are not only two complexes, but many.

Secondly, we have direct evidence contradicting de Heusch's supposed date of diffusion ca. 1840. It concerns the eastern Kongo nzo Zongo, which de Heusch believes to be derived from the Yaka mikanda, where Lunda influence is quite strong. Nevertheless nzo Zongo is described without being so named by Buenaventura de Corella in his short relation of pagan rites written before August of $1649 .{ }^{56}$ He tells use about nzo acuzea, "the house of circumcision." He stresses the collective character of the initiation and the role of fire in the lodge and claims that initiation was necessary before marriage. And a dictionary from the period has Zongo meaning "marriage." Its geographical distribution then, was similar to what it was in about 1900 , existing both in the area of the mission of Inkusu and among the neighboring Zombo. ${ }^{57}$ Circumcision itself was widespread among the Kongo. The Carmelites, mentioned it in 1584 and Lopes speaks of it in a Loango context, and again when he described the Tio. ${ }^{58}$ This does not imply either collective circumcision nor an initiation school. Indeed we are not quite certain from these sources that circumcision was universal in all parts of the Kongo, only that it was more widespread than just at Inkusu and anong the Zombo.

The link between initiation rituals and masked performances is minimized by de Heusch. Conversely, De Sousberghe held it to be essential and claimed that Pende tradition holds that they learned the rituals from people on the right bank of the Upper Kwango, presumably in the seventeenth century. ${ }^{59}$ Such claims warrant further examination, even if we do know that the Pende actually moved from that area. Still, the distribution of mukanda rituals would favor an origin in Angola and certainly must date well before 1649 if the eastern Kongo had borrowed the "movement" from their neighbors in the Kwango valley by then as is the 
usual claim. De Heusch rightly excludes a Ruund origin (467) because the complex does not exist in the heart of the Luba empire pace White and Papstein. But the latter does show that the custom spread from a north-central Angolan area where Cokwe, Lucha$z i$, Mbunda, and Ndembu lived in close proximity. He postulates a century for this, from ca. 1525 to $c a$. 1625. Moreoever it is probably significant that mukanda is not specifically mentioned in Luvale tradition until the early nineteenth century. ${ }^{60}$ Note, however, that the Kuba claim to have it by the 1650 s and to have borrowed it from the Kete, who had it from the Pende.

To sum up, by the mid-seventeenth century mukanda existed among the eastern Kongo and was claimed by the Kuba as well. It did not yet exist on the Upper Zambezi but the Pende claimed that it did exist ca. 1600 on the Upper Kwango. Certainly the whole complex is fairly old, whatever a more in-depth study might reveal about its probable point of origin.

The argument that the maintenance of a single term to denote initiation indicates a recent spread is not as safe as it may look. Mikanda means skin. ${ }^{61}$ The meaning "foreskin" derives from this just as in the kingdom of Kongo "paper, book, letter" also derived from this meaning by 1650 at the latest. ${ }^{6}$ The distribution shows that no such initiation complex existed in the area before this ritual spread and that the spread itself may have been fairly rapid. The case is similar to the use of the term makaya "leaves" for "tobacco" as opposed to various terms used for "manioc." Both these plants were introduced at the same time, but "manioc" replaced existing yams and hence its terminology varied more, while "tobacco" was brand new.

What then of the similarities between mikanda initiations and those of southeast Africa? Insofar as they are not contrived by de Heusch, they all have to be explained as fundamental resemblance in rites of passage and as similarities due to indirect contact such as has been going on for many centuries between the different parts of Africa.

A last remark is in order. De Heusch relies on Ellenberger (1919!) for his specific evidence about the Kololo. This will not do. Once again, he should have consulted the whole body of literature about the question. It is, once again, an inadmissable shortcut through sources and historiography.

\section{A Grand Hypothesis: Proto-Bantu Mythology}

\footnotetext{
"So many coincidences,--which correspond to the same structural schema--encourage us to advance the following hypothesis: Among the undivided proto-Bantu linguistic community, there must have existed a myth of origin from which the Kuba on the one hand and the Karanga-Venda on the other elaborated their original conception of kingship along different historical paths. The persistence of the sun king, who controls lightning
} 
and rain with the agreement of a snake nature spirit, assimilated to the supreme Being among the Lunda, could not simply be the product of sheer convergence" ( 363 ; cf. $10,368-69)$.

The grand hypothesis results from a comparison between the shortest myth reported here (M 51) and the Kuba myth (M 16) which has been presented before. M 51 is Venda and states that originally "men and all creation were held in the belly of a python, who vomited them" (307). Chapter 8 opens with this and the python stays with us for two chapters until the "provisional conclusions" (368), where it is rephrased as follows: "We began by postulating not without hesitation, the existence of a common Bantu myth, in which the world is created by expectoration (vomiting or the production of words): the demiurge is an aquatic python. He was perhaps androgynous." Mboom, who for the Kuba is a spirit associated with the sky and anthropomorphic, thereby becomes an aquatic androgynous python...

Dumézil provided the model for this hypothesis. A classical scholar interested in comparative religion since the 1920s, he first adumbrated his theory about the three functions of Indo-European kingship in 1938, holding that Indo-European mythology basically was maintained in all the cultures that developed from Proto-Indo-European roots. ${ }^{53}$ He spent his life developing this thesis and reconstructing Proto-Indo-European mythology. His industry has been remarkable and he has left no potential source unexamined. His citations are careful. His method was structuralist well before Lévi-Strauss but in the vein of Propp, whose work he seems not to have know, although in time his presentation of diagrams may have borrowed from structuralism $\grave{\alpha}$ la Lévi-Strauss. His reception has been lukewarm on the whole; most scholars feel that he has been too speculative to be convincing, primarily because of the nature of his materials. How do you actual1y "prove" that parallels in reflexive mythologies must actually show proto-mythology. After al1, narrative material or ritual is not unconscious 1inguistic data.

De Heusch has been the only structuralist of the Lévi-Straussian persuasion who has been impressed by Dumézil and this ever since his Le Rwanda et la civilisation interlacustre. Etudes d'anthropologie historique et structurale. ${ }^{64}$ In time the influence has grown. Early on in Rois nés he states (7) that, "While remaining faithful to the program set by Lévi-Strauss for the American domain, our own course meets more and more clearly that of $\mathrm{G}$. Dumézil, who commands attention by his magisterial study of the archaic Indo-European societies." (See also 7, 77, 79, $155,338,355)$. On 355-56 he claims that Dumézil "has demonstrated that the fundamental religious ideology of the Indo-European societies has remained unchanged over two or three thousand years despite the various transformations to which it has been subjected...after the bursting of the initial linguistic community." And thus he attempted to emulate his endeavor, but for the Bantuspeaking world.

The full argument developed on $368-71$ aims at equating the 
Venda and Kuba myths by claiming that in both cases it may appear that the celestial nature spirit (Raluvhumba and Mboom) are preeminent though in fact they must be installed by the spirit of the waters. A variant of the Mboom myth has Mboom being created by the primordial marsh. To me, though, this may be a different myth, the product of speculation about the origin or origins and an attempt to fit several origin myths together. In the next paragraph the solar character of Venda and Kuba kingship is stressed because the creator figure is automatically equated with a king. Kingship, however, is lunar among the Luba and Karanga and solilunar among the Lunda. The geographic distribution convinces him that the solar form is older, even though in a typical reservation (370) he begins by asserting that the question of what is oldest makes no sense to the structuralist, "while historians could object that the answer is beyond us, unverifiable." Nevertheless, on we go. The archeological findings at Sanga in Shaba are linked to the now-discredited second dispersal of the Bantu according to Guthrie and de Heusch concludes that the lunar and Venusian variant is a well-preserved variant of the proto-Bantu cosmogonic myth that elsewhere has been the ideological substratum of a solar kingship. Does this mean that the lunar variant is younger? Equally old? Neither? A neat ambiguity prevents us from concluding, even though the Kuba/Venda form is labeled "ancient" on the next page. The suggestion follows that the lunar variant is East African, without citation of Schebesta's 1926 article that is listed in his bibliography. 65

What are the implications of such a hypothesis? It presumes a single Proto-Bantu linguistic community, something that is no longer accepted without further specification by linguists. ${ }^{6} 6$ It claims not only that a myth of origin survived from three to perhaps five thousand years, but that we can find out just what this myth was. It does so on the basis of rejecting convergence as an explanation and ignoring borrowing. But convergence is a strong possibility. After all, people do speculate about the origin of mankind and nature and probably have done so ever since mankind has been self-conscious. A creator is either seen as anthropomorphic or not, most often the former. The act of creation must be an emanation of such a person, as in the Book of Genesis. Expectorating or self-creation is not uncommon. In Ancient Egypt one myth has $\mathrm{Ra}$ (the sun!) create the world by spitting, rather close to vomiting. ${ }^{7}$ Baumann thought that this myth was actually closest to the Kuba version and, horresco referens, I must agree that it is closer than the Venda myth. ${ }^{8}$ As for an aquatic chaotic milieu, sea, or marsh, should we not also take into account the many myths of origin that mention them, from Sumer, the Indian Ur-ocean, the southeast African primordial marsh to the Inca version of lake Titicaca, and many Polynesian accounts? ${ }^{69}$ In central and eastern Polynesia we find an earth mother and sky father as in Egypt and the Arawa Maori even have the equivalent of the Egyptian Shu, separating sky and land. Convergence must be accepted in such matters as the strongest possibility. De Heusch did not consult Baumann's work on Africa 
in this regard. As early as 1933 it was known that the Yoruba, Bini, and Baule visualized a primordial sea, or that many African thinkers in various places speculated about a wet chaos with rocks soft enough to retain the first footprints. ${ }^{70}$ These include Venda (M 51:307) and many southeast and central African groups. Why, then, should this Kamba, Nyanja, Yao, Makwa, Bemba, Lunda, Thonga, Tswana, and Sotho tale not be a better candidate for an Ur-Bantu myth? Of course the Fulani of Futa Jalon, the Dakka of northern Cameroun, the Baule, Mosi, Bini, Bassari, and Wute share this perception and make this difficult to accept. Now, in this case convergence may not be the answer to such specific imagery but given the widespread exchange of folklore motifs, borrowing is.

Why should these creators be linked to kingship? Do peoples without formal kingship really not have myths of origin? Why should solar kings (if that concept be true) stressing heat and dryness as beneficial not be found in wet environments such as that of the Kuba (but not the Venda) and lunar kingship with its stress on beneficial wetness in environments where droughts are a problem? This is a plausible argument, and one often invoked by de Heusch (see index sub "sécheresse"). It is easily faulted, however, (e.g., the Venda environment is quite susceptible to droughts) and means little. There is no ethnographic evidence to equate symbolism of kingship with speculation about the creation of the world. The first is a metaphor, not "real," whereas the second is a search for the "real." Only when a heavenly symbol for kingship, such as the sun, becomes "real"--as happened at times in ancient Egypt--can it be tied directly to a myth of origin. Among the Kuba, kingship begins with Woot, who may be the first man, but was not the Creator.

Still arguing about the speculative activities of mankind, it probably is rare in a given oral culture that all agreed on one invariant myth of creation. The existence of different speculations is more likely. Why then privilege one to the exclusion of all others? Why trace that one back to an Ur-Bantu environment as if it were the only myth, held by all at so early a date? Is it not more common for myths of origin to be multiple, competing, compromising, conflicting? The Kuba do not differ in this from the Sumerians, or the ancient Egyptians, or the Greeks, or the Chinese or Japanese. And if we are to be told that such reasoning would never have allowed Dumézil to reach his conclusions (338) we might retort that he is not our household deity or that his quest dealt with the conception of functions or aspects of kingship and that we tend to believe him when he is most detailed and aligns not just two but almost all branches of the Indo-European family to convince us, rare though such passages may be.

But is there really a congruence between the Kuba and Venda myths to begin with? Might it not just be a figment of the analyst's mind? I believe that it is in fact a kind of mirage. For this we must turn back to the reasoning in chapters 8 and 9 . The elliptic Venda myth is more complex than we stated. In the beginning all was water with the python in it. He vomits nine crea- 
tures that leave their tracks on the soft rock. When they died these spirits became the heavenly bodies and the sun and the moon were the first rulers. In a second world they produced twins, who were of different gender and procreated among themselves and from whom mankind stems (307). ${ }^{71}$

Apart from the vomiting this looks rather different from M 16, the Kuba myth presented in our first section. How then do we go from one to the other? In chapter 8 de Heusch attempts to establish a relationship between the Venda myth and myths attributed to ancient Zimbabwe. Venda and Shona myths are seen as transformations of each other. They tell of kings associated with water and aquatic beings (python or spirit) as well as with heaven and its denizens (Raluvhumba and Mwari). Kings mediate between the two and thus regulate the seasons. In Zimbabwe they were associated with the moon and their reigns were short (the moon dies), with implied regicide. Among the Venda, on the other hand, they were associated with the sun and their rules were long, at the expense, however, of their own fertility. All is not explained by this, though, for de Heusch states that "for mysterious reasons, their successors [of the solar kings of Zimbabwe] are lunar kings, holders of Venusian fire" (326). One of the conclusions of this chapter reads: "Once more, one verifies [sic] that historical legends have little to do with events, even if the latter jostle their texture" (327). But the reader should know that this applies to stories cited about mhondoro spirits, tales about unspecified kings, princesses and queens, and tales about the origin of later kingship. Even so, we may not quite agree that events do not leave any trace except for minor details. After all, kingships were at one time established. So were the cults of spirits and the tales explain why such events occurred. They are apologues.

The Shona myths de Heusch uses stem from an anthology of Frobenius' writings as translated into English, a foundation so thin that we must not be surprised when it cracks. ${ }^{72}$ What de Heusch takes to be the foundation myth of Great Zimbabwe relates to the establishment of the chiefs of Maungwe and in Manyika where Frobenius gathered his data. This whole chapter must be read with Beach's work in hand. ${ }^{73}$ Not only will the historical background become clearer and confusions between totem names and names of descent lines be clarified, but one finds that many other versions of the myths cited were recorded during the colonial period. Having the anthology at hand makes clear that once more de Heusch has provided titles and in one case (366-67: Runde) conflated two variants of one tale. For M 56 (329) the new title "The Tower and the Morning Star" mentions a non-existent tower, so that his comments about the tower of Babel $(330,367-68)$ are not apposite. The summary there leaves out some motifs ("mats") and almost an entire episode (the queen verifying her daughters' virginity). Nor are the "ancestors" found in the summary. 74 In fact it is odd that de Heusch dwells on the tower motif when both the anthill as grave motif (see Nyony aNgaan in the Kuba myth) and the cosmic tree are present here and widely dispersed in Africa and beyond, at least for the tree. A reference to Zimbabwe 
as "those mysterious ruins, without an equivalent in the Bantu world" (312) is unforgivable. In short we find all the familiar shortcomings of structuralist analysis here.

De Heusch builds up a congruence between Venda and Kuba myth in chapter 9. The Venda python is first compared to the rainbow snake of the Yombe of Lower Zaire and (334) a detail in Venda belief is actually explained by a detail in the Yombe tale. The Venda believe that a rainbow fish accompanies the python, while the Yombe rainbow once appeared as an eel or a catfish. Because the Yombe rainbow snake is now a "fish" now a rainbow snake, but also thought of on occasion as a python, the Venda catfish mist be a double of the python there. Once again, "we cannot doubt that Mbumba and the Venda python are fundamentally kin," (335) for the name for the rainbow snake among the Yombe is Mbumba. This first comparison already convinces de Heusch that southern and central African myths must have a common source (335). Having then linked pythons among the Venda, Zulu, and Swazi and recalled earlier discussions of rainbow snakes in Central Africa (The Drunken King) and having gone through an aside comparing the Luba Nkongolo (king and rainbow) with the $\mathrm{Zulu}$ princess of rainbows (Inkosazana), the stage is set for a discussion of "the primordial snake in the Bantu world" (342).

This begins by asserting that the Venda myth is an old version of "the Bantu cosmogenesis" (343, emphasis added) because its subject matter also occurs in the Kuba myth. The link is the equation of Mbumba, the Yombe name, with the Kuba name Mboom (344), at which point we are told that "Vansina does not hesitate to bring them together." The footnote supporting this-slightly incorrect as happens in this book--refers to $324 \mathrm{n} 16$ of The Children of Woot, which reads: "It is not impossible that Mboom/Mbomba has a relation with the Kongo spirit Mbumba..." And I thought I was being cautious! The truth is that we still do not know whether there is such a relationship because the distribution is interrupted, because the vowel openings do not allow certainty, and because the Kongo tones are unknown, but an equation is, as I said, not impossible. Even if the name agreed, though, the major contents of the concepts need not. I recent1y argued that Mboom/Mbomba may well have been a term for a nature spirit/ogre, perhaps an ogre even earlier in the Mongo world before he came to be cast as a creator God. ${ }^{75}$ Names cannot simply be equated with concepts." De Heusch's schema: "Mbumba= Mboom; therefore: a rainbowsnake=a pale skinned spirit" will not do. Mbumba, by the way, is a major spirit, whose rainbowsnake and occasional python shapes are not his most ordinary appearance. The epithet further given to Mboom in the passage where the 'equivalence' with Yombe occurs, "primordial aquatic spirit," is simply wrong, even though Mboom did create by vomiting into the primeval water.

Once the link is forged, the formal Venda/Kuba comparison ineluctably follows (346): 
Kuba

(i) Mboom

(ii) vomits celestial bodies

(iii) water, land, sky created

(iv) dualism: Mboom = heaven Ngaan $=$ water

but: Ngaan $=$ feared

(fear of tornado)

inversion due to difference of climate between the two areas
Venda

python

vomits nine celestial bodies

water, land, sky created

dualism: Raluvhumba = heaven

python = water

but Raluvhumba $=$ feared

(fear of drought)

From there we jump to 363 , as the intermediate pages are but another excursus, and we find

(v) crocodile linked to king crocodile linked to king

From this the grand conclusion follows.

The appearance of Ngaan in this comparison derives from Kuba data used by de Heusch to conclude that "everything happens as if the primordial snake, which is subsumed by the very name of Mboom, has become double." The formula to convince plus the Mboom/Mbumba hypothesis, and the claim (never explicit) that the content of the concept was "a snake" as well as the indefensible assertion that Mboom is now double are now all in a single sentence (363). The Kuba data only make clear that Mboom rules in heaven, Ngaan in the water, Woot upstream, and Mweel downstream, and, in another myth, that Mboom created the nine or eighteen "good things" and Ngaan the same number of "bad things." The association of a crocodile with the Kuba king is correct, however, and there is a link to the cult of Ngaan, although the crocodile is one of the children of Mboom.

of the similarities (i) is rejected; (iv) does not appear in the Venda or the Kuba myth at all, the Kuba connection being quite indirect; ( $i i)$ and (v) are acceptable; while (iii) stands in error. The Kuba sequence--water, sky, land--differs from that of the Venda--water, soft land, sky.

(ii) and $(v)$ remain but $(v)$ is not part of the myth of creation at all. The similarity in (ii) is the product of fundamental convergence; any account of the universe has to include the celestial bodies. For vomiting or expectoration, convergence is also likely. As to ( $(v)$, a form of fundamental convergence is also involved. Wherever there are crocodiles, they have struck the imagination. They are the predators of the rivers as leopards and lions are on land and eagles in the sky. So crocodiles are readily linked to kingship as symbols. Moreover, the correspondence between Kuba, Venda, and Shona are not close.

Kuba

first king rises on a miraculous crocodile

crocodile scales are part of the major royal charm inam 


\section{Venda}

candidate king must swallow a stone from a crocodile king protected by desiccated crocodile charm

\section{Shona}

crocodile along with eagle on sculpture of Great Zimbabwe

If de Heusch wants to show unusual similarity, he must prove that it is exceptional and, moreover, that there is a link with the myth of origin. Short of this there is no point in spending time dealing with crocodiles in other cultures, African or elsewhere, or discussing their relationship, through ritual, art or otherwise, to kingship, nor even about their equivalence with dragons in Asia. ${ }^{76}$ There are no grounds for the grand hypothesis. In its regard de Heusch addresses two, presumably rhetorical, questions to me (355). How does one explain that so many Bantu-speaking people of southern Africa claim, like the Kuba, that humanity emerged from a primordial marsh? The most likely explanation is convergence. And why would the Venda attribute the vomiting of the world to a python, so strangely similar to the Kuba Ngaan? The answer is that the similarity is spurious; De Heusch devised it.

\section{VI}

"The Archeology of Bantu Thought"

Part of chapter 10, devoted to the Kuba, is a polemic with me. First, de Heusch gathers data about the spirit Ngaan, the counterpart of Mboom. Then ( $347 \mathrm{ff}$ ) he discusses the notion of twinship in Kuba myth and practice while stressing the obvious dualism that exists in Kuba practice and thought. He raises questions of importance to all historians. If, he says, my account of the selection processes in oral tradition is correct, we must re-examine the foundations themselves of "la pensée sauvage" (354), and re-evaluate the boundary between myth and history. He complains that my positivistic reductionism (a contretemps over the origin in a "marsh") actually makes every comparative inquiry impossible by imprisoning the historian of religion in a cell of particularistic history. And it is interdependent with the functionalist perspective (355). He would rather follow Dumézil and by doing so, he sees the possibility for "an archeology of Bantu thought" (356).

Taking the questions in reverse order of importance, we can start with the second, barring for now specific assertions about the Kuba this and the Kuba that. When Dumézil claimed that fundamental religious ideology remained unchanged, he stresses similarities at the expense of change, which was eliminated as mere "transformation." But, similarly, we can argue that nothing has changed very much in fundamental political organization since ancient times as kings are transformed into republican leaders, 
emperors, absolute monarchs, constitutional monarchs, or figurehead presidents. Have we not done away with most of the past reality of political history? It is perfectly possible for IndoEuropean notions to have survived the millennia and Dumezil deploys a rich battery of specific arguments based on philology and on the role actors play in myths (as Propp did before him) and so tried to prove that notions, indeed structures, have survived. He often lacks conviction in the final analysis because so much speculation remains to which any number of alternative explanations would fit equally well. Because of his exiguous data and long time-spans, he can achieve at best a low level of probability. That is not to deny that there are long-term trends in religion. Apart from Christianity or the other monotheistic religions, one can invoke the run of ancient Egyptian religion over better than three thousand years. But these are religions using "books." Would that remain true if dogma mattered less and participation in ritual more? Who knows?

Withal, even if it were possible, we cannot expect any myth gathered in the last century or two to be "the" common Bantu myth of origin. There must have been several even at the "beginning." And then the spread of the Bantu speakers, their incorporation of unknown but large numbers of other peoples, and their movements in so many natural and human environments make it certain that we would not be able to recognize reflexes of common Bantu "thought" if we met them head-on. Nor can we forget the immense amount of borrowing back and forth that has been going on among Bantu speakers during their entire history. Here the linguistic evidence of convergence is overwhelming. Unlike language, myth is a discourse, much more complex and variable than linguistic form and hence ultimately less traceable by comparative methods similar to those used in linguistics. That remains as true for the Indo-European world as for any other. Very careful work can yield bits of meaning, not much more than what etymological study can uncover.

Dumézil remains particularistic by de Heusch's standard. He is, after all, in the thrall of Indo-European cultures. Even Lévi-Strauss was bound to the Americas (or, in an earlier study, to southeast Asia) and so is de Heusch to Bantu-speaking Africa. A no-holds-barred comparative method can only be used to demonstrate some property of condition common to all humans but, as these illustrious examples show, their limitations are certainly not linked to functionalism.

I agree with de Heusch that we must re-examine the foundations of thought--which is not just "pensée sauvage." Yes, ora1 tradition selects and structures, but oral tradition is not a reified Spirit. What selects are human minds and as they select in the same fashion, selection has something to do with the functioning human brain. So when we find evidence for structuralizing we must look for the memorizing process of the mind. Memory is a process that recreates. Because it is action it cannot be distinguished from creation itself--that is the operation of the mind in general--as is increasingly recognized.77

There is a way to find "the laws of the mind." It consists 
of comparing the properties of what appears to "distort" memories in the generation of both symbols and thought. Hypotheses about what happens can then be linked to what we know about the structure and the operation of the brain, from perception to reasoning by logic or analogy to self analysis. It is a program that could succeed in another century, perhaps sooner. Levi-Strauss did not show how savages think. He only showed what happens to his own thought when he acts "as if" he were a Bororo, a Nambikwara, or a Kwakiut1.

All history as reconstruction of the past is of course mythical. 78 Myths are held to be "true." De Heusch is to be faulted for not using all the traditions about the past, however recent that past, and considering them myth. But, conversely, historical accounts reflect the past. The we11-known problem is to find exactly how a set of data reflects the past as well as how it expresses the present. The succeeding problem, then, is how to reconstruct the past most objectively, and in doing so create a new myth. Not because the account is not true, but because it will be held to be true.

Positivistic reductionism? Two -isms at once! De Heusch's stems from his ire at suggestions that Kuba cosmogony might recal1 the great marshes of the Ruki, where Kuba ancestors may once have lived and to link their dualism of Mboom and Ngaan to a dualism of fishermen and landlubbers, as is common in those area. I had argued "may even go back" and "one can even argue", meaning that it is something that can be thought of, just as Venda value rain because of droughts and Kuba the dry weather because of tornadoes. ${ }^{79}$ I no longer believe that this is still possible for the Mboom/Ngaan opposition but it is still not impossible with regard to the Ruki. ${ }^{8}$ But it can never be proven and I would certainly not reduce a whole cosmogony to it. It is one thing to recognize the possible influence of the environment, another to reduce myths to that. Does de Heusch reduce his Common Bantu myth to a dualism between dry and wet seasons?

Reductionism in these matters would be a sort of functiona1ism, for where that particular -ism errs is not in its assumptions about functions but in the reduction of an explanation merely to function and to assume that functions, which are no less the product of the mind of the researcher, are in fact entities "out there." Only concrete ethnographic evidence of items in actual action in actual circumstances can prove functioning. However, once a function, say of a Kuba myth, has been ascertained in that way, it does not by itself explain a myth since alternative myths might have done just as well. Function merely places a feature in its social and natural setting.

A discussion of the interpretation de Heusch gives to specific Kuba data (344-62) could be very long. It seems to me that it would have been natural for de Heusch to ask me for data or comments as he was writing this, rather than to discuss other matters when we met and artificially open a dialogue now. Meanwhile, I have attempted to disentangle the questions raised by the several creators in Kuba myth. ${ }^{81}$ The oldest creator historically is Mboom, who is also the oldest creator figure in the Mongo world. The cult 
for Ngaan arose later and was linked to political ideology and ritual, but began to be downplayed as early as the seventeenth century, when the concept of Ncyeem was introduced. Later, royal ritual developed and focused more and more on the king as nature-spirit. The dualism of Mboom and Ngaan pictured as "very ancient" by de Heusch may have begun in the sixteenth century. The earliest glimpse we can trace back of the Mboom figure shows a half-person figure, rather like ogres are visualized in the Mongo world.

In a passage about the Siamese twins Kop aNgaan and Nyony aNgaan, de Heusch rhetorically exclaims: "It obviously is not in the equatorial forest that such a strange creature can be met." (335) Ironically, it is precisely there, among the Mbole, that we encounter these names. Nkofi is an alternate name for the creator and in the same area Nyonyi personifies death or sickness. ${ }^{82}$ Nyonyi aNkofi is an expression meaning "death caused by God." 83 Moreover, among the same Mbole we find the closestknown equivalent to the Kuba myth. Moma (Mboom) has three children--the sun, the moon, and man. They are punished by death for disobedience. One resuscitates every morning, one dies for a mere three days, and one dies for good. ${ }^{84}$ No wonder that Nyony a Ngaan in the myth recorded by Torday dealt with the origin of Death! Perhaps there are no twins in the mythology of the forest-dwellers but there is a mythology and we must first compare Kuba mythology with the Mongo area because the Kuba stem from there. Between Mbole and Kuba, however fragmentary our state of knowledge, we can at least say that the name for the creator and the conception of creation as a genealogy "with children of Mboom" are identical, which is far, far more than for the Kuba and Egyptian or Venda myths de Heusch cites. Without going into detail, I point out that there are several errors for 347-53 and 358-62, of the kind already mentioned. The most common error is to extend analogies beyond what Kuba data indicate and to ignore the very real existence of boundaries in Kuba thought. For instance, the king is sometimes named Kop aNgaan when his role as Fate is underlined. He will then roar as a leopard. But this does not mean that the myyesh, the king's spokesman, can be identified with Nyony aNgaan (as on 348). The relationship between king and myjesh belongs to a different universe of discourse. If we fail to pay attention to boundaries, the king becomes the sun and the moon at the same time, and yet the sun as opposed to the moon, etc. Contradictions abound in Kuba imagery once the universe where they are applicable is ignored. The whole table about "twinship and kingship" (361) is marred by this, leaving aside the confusion between "twins" and dualism. In it artificial junctions are made, actually-occurring pairs are severed or forgotten, and whole levels are ignored. But it would not be useful to present another and different table for the proof of the pudding is that doing so would not alter de Heusch's conclusions about twinship on the next page at all. That both validates and indicts the whole method. This observation permits us to conclude that there never can be a successful structuralist approach to historical reconstruction. 


\section{NOTES}

1. A review of Luc de Heusch, Rois nés d'un coeur de vache (Paris, 1982).

2. Atkinson, "The Traditions of the Early Kings of Buganda: Myth, History and Structural Analysis," HA, 2 (1975), 17-58. See also various contributions in J.C. Miller, ed., The African Past Speaks (Folkestone, 1980).

3. (Paris, 1972). A translation has just been published: The Drunken King (Bloomington, 1982). Citations are to this edition.

4. J.J. Hoover, "Mythe et remous historique: A Lunda Response to De Heusch," HA, 5 (1978), 71; T.Q. Reefe, "Traditions of Genesis and the Luba Diaspora," $H A, 4$ (1977), 184.

5. E.g., John Yoder, "The Historical Study of a Kanyok Genesis Myth: The Tale of Citend a Mfumu" in Miller, The African Past Speaks, 82; Robert Schecter, "A Propos the Drunken King: Cosmology and History" in ibid., 108-13; and Randal1 M. Packard, "The Study of Historical Process in African Traditions of Genesis: The Bashu Myth of Muhiyi" in ibid., 157.

6. R.G. Willis, On Historical Reconstmuction from Oral-Traditional Sources: A Structuralist Approach (Evanston, 1976);

7. idem., A State in the Making: Myth, History, and Social Transformation in Pre-Colonial Ufipa (Bloomington, 1981), 37 .

8. I am much loath to undertake this; we have been friends for thirty years. Yet exercises of the kind of Rois nés leads to great waste of intellectual effort. This constrains me to undertake this critique, not so much of Rois nés but of the structuralist 'method' in general.

9. René Cornet, Art royal kuba (Milan, 1982), 29, 308-309. Cf. Vansina, Geschiedenis van de Kuba (Tervuren, 1962), 118-19, 291.

10. Bertel Nathhorst, Formal or Structural Studies of Traditional Tales; the Usefulness of Some Methodological Proposals Advanced by Vladimir Propp, Alan Dundes, Claude LéviStrauss and Edmund Leach (Stockholm, 1969).

11. Esp. L.L. Thomas, J.Z. Kronenfeld, and D.B. Kronenfeld, "Asdiwal Crumbles: A Critique of Lévi-Straussian Myth Analysis," American Ethnologist, 13 (1976), 147-73.

12. Africanist anthropologists who aspire to be structuralists follow either Lévi-Strauss or Leach. T.0. Beidelman is not a strict structuralist because of his care to document his ethnographic data and his different goals. Structuralism must not be confused with all symbolic anthropology.

13. Alain Lieury, La mémoire: résultats et théories (Brussels, 1975), 48-52. Besides oppositions, similarities, superordination or subordination, and comocurrence are the mental mechanisms of association.

14. The classic case is that of the Dogon. Marcel Griaule, Dieu $d^{\prime}$ eau (Paris, 1948) was based entirely on the views of 
Ogotemelli but we will never know how far these have since become standard among the Dogon, perhaps driving out others; nor exactly to what extent earlier studies by the Griaule team were based on cosmological conceptions of other informants.

15. R.W. Willis, "The Literalist Fallacy and the Problem of Oral Tradition," Social Analysis, 2 (1980), 28-33. Willis badly confuses symbolic analysis with structural analysis.

16. Emil Torday and M.A. Joyce, Notes ethnographiques sur les peuples communément appelés Bakuba, ainsi que sur les peuplades apparentées-Les Bushongo (Brussels, 1910), 20. Vansina, Geschiedenis, 81. Fifteen other variants are known.

17. G. Hulstaert, "Le Dieu des Mongo," Anthropos, 219-20, 22324,227 . Note that the Yongo are a Mbole subgroup.

18. Vansina, The Chizdren of Woot (Madison, 1978), 29-34.

19. Marcel D'Hertefelt and André Coupez, La royauté sacrée de Z'ancien Rwanda (Tervuren, 1964).

20. Discussed in his Le Rwanda et la civilisation interacustre (Brussels, 1966), 158-363 passim.

21. Dumézil, Les dieux souverains des indo-européens (Paris, 1977), 252 .

22. André Coupez and Th. Kamanzi, Récits historiques rwanda dans la version de C. Gakaníisha (Tervuren, 1962); Albert Pagès, Un royaume hamite au centre de l'Afrique (Brussels, 1933); Pierre Smith, Le récit populaire au Rwanda (Paris, 1975).

23. Alexis Kagame, Inganji Karinga I (2d. ed.: Kabgayi, 1959).

24. Vansina, Ibitéekerezo (Center for Research Libraries, Chi(ago), six reels, Cat. No. MF-2739.

25. Coupez, Kamanzi, Littérature de cour au Rwanda (Oxford, 1970). The volume is cited in his bibliography, however.

26. Kagame, La notion de génération appliquée à la généalogie dynastique et à l'histoire du Rwanda des Xè-XIè siècles à nos jours (Brussels, 1959), 14-27, 80-86, discusses this source, called ubucurabwenge, ("Smithing intelligence"). His version is apparently the only one recorded. He fully published it in his Inganji Karinga, 93-99, but without commentary as to the circumstances of dictation or his actual source.

27. The names are best explained by P. Smith, "La forge de 1 'intelligence," Homme, 10 (1970), 11-15.

28. Vansina, La légende du passé: traditions orales du Burundi (Tervuren, 1972), 73. See also ibid., 55-68, 102 for a very general motif called fanany. Cf. Hermann Baumann, Dic Volker Afrikas und ihre TraditioneZzen KuZturen (Wiesbaden, 1975), 1: 625-26.

29. Smith, Récit populaire, 52-53; A. Lestrade, Notes d'ethnographie du Rwanda (Rervuren, 1972), 61-67.

30. A point made by Hoover, "Mythe," 67. Thus "sun" as opposed to "rain" or "clouds" is as valid as sun opposed to "moon" and hence neither is a strictly logical deduction from "sun," being neither sufficient nor necessary.

31. "Cow" in the sense of a head of cattle without gender indi- 
cation. Cf. Coupez/Kamanzi, Rêcits historiques, 60.

32. Ibid., 98-99.

33. Smith, "Forge," 17.

34. Coupez/Kamanzi, Récits historiques, 102-03, lines $79 \mathrm{ff}$.

35. Ibid., 62-63, Iines 11ff.

36. Smith, Récit populaire, $114 \mathrm{ff}$.

37. Nathhorst, Formal or Structural Studies, 58-59.

38. Smith, "Forge," 15.

39. Dumézi1, Mitra-Varuna (Paris, 1948), esp. 13-16. Cf. Dumézil, Les dieux souverains, 9-15.

40. Baumann, Schöpfung und Urzeit des Menschen im Mythus der Afrikanischen Völker (2d. ed.: Berlin, 1936) 2: 256-260. Although much more is known today, some west African cases were known even then.

41. Peter Brown, Cult of the Saints (Chicago, 1981), 81.

42. David Newbury, "The Clans of Rwanda: An Historical Hypothesis," Africa, 50 (1980), 389-403, shows how damaging this can be and how unrealistic it is.

43. E.g., T.N. Huffman, "Archaeology and Ethnohistory of the African Iron Age," Annual Review of Anthropology, 11 (1982), 133-50.

44. Smith, "Forge," 6, following Kagame, Notion, 87; Vansina, L'évolution du royaume manda dès origines à 1900 (Brussels, 1962), 25 .

45. J.K. Rennie, "The Pre-Colonial History of Rwanda: A Reinterpretation," Transafrican Journal of History, 2 (1972), 11-53; Francis Van Noten, Les tombes du roi Cyirima Rujugira et de la reine mére Nyirayuhi Kanjogera (Tervuren, 1972).

46. Miller, "Listening for the African Past" in Miller, African Past Speaks, 24-34.

47. Robert L. Layton, The Ar,thropology of Art (New York, 1981), 4-5.

48. Henri A. Junod, Moeurs et coutumes des Bantous: Za vie d'une tribu sud-africaine (Paris, 1936).

49. Baumann, Schöpfung und Urzeit, 268-72 gives the Africa-wide distribution of the chameleon as bringer of death, which is the theme (408-09) of de Heusch, who limits himself to Rwanda, Thonga, Venda, and Zulu (228).

50. Junod, Moeurs, 85-86. The last line of the French translation was detached in error from the preceding text, explaining the confusion of de Heusch. But the original Thonga had no such error and even a cursory comparison of original and translation shows it.

51. Hugh A. Stayt, The Bavenda (London, 1968).

52. David N. Beach, The Shona and Zimbabwe (London, 1980), 10708 .

53. Junod, Moeurs, 74 .

54. R. Wagner, "Zoutpansberg: The Dynamics of a Hunting Frontier, 1848-67" in Shula Marks and Anthony Atmore, eds., Economy and Society in Pre-Industrial South Africa (London, 1980), 335-36. The initiation rituals were then very new among the Venda.

55. Baumann, Völker Afrikas, 596. 
56. Louis Jadin, L'ancien Congo et l'Angola, 1639-1655 (2 vols.: Brussels, 1975), 2: 1151-65, esp. 1152 .

57. Ibid., 1164. A second account by Bonaventura d'Alessano is found on 1172 (Original in A. Brásio, Monumenta Missionaria Africana (Lisbon, 1965), 10: 395-400.

58. In Brásio, Monumenta, 4: 399; Willy Bal, Description du royaume de Congo et des Contrées environantes (Louvain, 1965), 31,34 .

59. Luc de Sousberghe, L'art Pende (Brussels, 1959), 6-7.

60. Robert J. Papstein, "The Upper Zembezi: A History of the Luvale People, 1000-1900," (Ph.D., UCLA, 1978), 174-79.

61. Malcolm Guthrie, Comparative Bantu (Farnham, 1970), 3: 265, CS 1002 ("Ietter"), 1003 ("skin"), 1004 ("strap").

62. Joseph Van Wing, C. Penders, Le plus ancien dictionnaire bantu (Louvain, 1928), 206.

63. Dumézil, Les dieux souverains, 9-15, for his own estimate of his work.

64. (Brusse1s, 1966).

65. Paul Schebesta, "Die Zimbabwe-Kultur in Afrika," Anthropos, 21 (1926), 484-545. De Heusch rejects Kulturkreislehre in general, but not in this instance.

66. Patrick Bennett and Jan Sterk, "South Central Niger-Congo: A Reclassification," Studies in African Linguistics, 8 (1977), 241-73 and Kay Williamson, "The Benue-Congo Languages and Ijo," Current Trends in Linguistics, 7 (1971), 245-306.

67. Adolf Erman, Die Religion der Aegypter (Berlin, 1934), 62, 90 (Atum spit the Gods Shu and Tefnet. "To spit" is 1inked to the folk etymology for Shu). See also Edmond Drioton and Jacques Vandier, L'Egypte (Paris, 1952), 81, and Vandier, La religion égyptienne (Paris, 1949), 33. A11 authors make clear that this is but one cosmology, backed by the priests of Heliopolis. It was not the oldest one reported.

68. Baumann, Schöpfung und Urzeit, 190.

69. Roslyn Poignant, Oceanic Mythology (London, 1967), 29.

70. Baumann, Schöpfung und Urzeit, 186, 189.

71. The importance of twins in Africa need not be stressed. Twins as a means to propagate the human race occur elsewhere in Africa, as among the Fang or the Ziba.

72. Eike Haberland, ed., Leo Frobenius, 1873-1973 (Wiesbaden, 1973), 192-221. The originals are from Frobenius Erythräa: Länder und Zeiten des heizigen Königsmordes (Ber1in, 1931), 114-244. The data come from his $1928 / 1930$ trip. Anyone using Frobenius is well-advised to check his published texts against his own notebooks, preserved at the Institute in Frankfort that bears his name.

73. Beach, Shona and Zimbabwe.

74. Haberland, Leo Frobenius, 209-11.

75. Vansina, "The History of God Among the Kuba," Africa [Rome], 38 (1983).

76. Among the iconographic ancestors of St. George and the Dragon must be reckoned a fourth-century relief showing Horus killing a crocodile, perhaps the former god Sebk. See Pierre du Bourguet, L'art copte (Paris, 1968), 78. And 
who does not know about dragons in China where they represent the water? See Marimus $W$. de Visser, The Dragon in China and Japan (Amsterdam, 1913). Passim.

77. E.g., Frederic C. Bartlett, Remembering (Cambridge, 1964); G.M. Edelman, "Through A Computer Darkly: Group Selection and Higher Brain Function," Bulletin of the American Academy of Arts and Sciences, 36 (1982), 20-49.

78. De Heusch refers here to Children of Woot, $322 \mathrm{n} 1$.

79. Vansina, Children of Woot, 31, 45.

80. For the argument see Vansina, "History of God."

81. Ibid.

82. Hulstaert, Dieu des Mongo, 219, 223.

83. Ibid., 228 .

84. Ibid., 227. 